\title{
How do permeable fractures in the Triassic sediments of Northern Alsace characterize the top of hydrothermal convective cells? Evidence from Soultz geothermal boreholes (France)
}

\author{
Jeanne Vidal ${ }^{1 *}$, Albert Genter ${ }^{2,3}$ and Jean Schmittbuhl ${ }^{4}$
}

* Correspondence:

j.vidal@unistra.fr

${ }^{1}$ EOST, University of Strasbourg, 1 rue Blessig, 67084 Strasbourg Cedex, France

Full list of author information is available at the end of the article

\begin{abstract}
Background: The thermal regime of the Upper Rhine Graben (URG) is characterized by a series of anomalies near Soultz-sous-Forêts (France), Rittershoffen (France), and Landau (Germany). These temperature anomalies are associated with groundwater circulation in fractures and faults distributed in the Cenozoic and Mesozoic sedimentary cover associated with and connected to fractures originating deep within the Paleozoic basement. The present study helps to understand the convective cell structure in order to optimize geothermal borehole trajectories.
\end{abstract}

Methods: The work concentrated on a detailed interpretation of the geophysical and geological logs from Soultz geothermal wells mainly from the topographic surface to the Triassic formations, at between 800- and 1,400-m depth above the deep granitic basement.

Results: The analysis of drilling mud logging data and geophysical well logging data from the deep Soultz geothermal wells (GPK-2, GPK-3, GPK-4) reveals the occurrence of nine fracture zones situated at depths greater than $900 \mathrm{~m}$ in the limestones of the Muschelkalk (Middle Trias) and the sandstones of the Buntsandstein (Lower Trias). Based on indications of total or partial mud losses, these fracture zones have been classified as permeable or impermeable.

Conclusions: Permeable fractures between circa 900-m depth and 1,400-m depth are connected to a large-scale fault and control the top of the convective cells. There is no indication of permeability in the formations above the Keuper layer, and the uppermost part of the sedimentary cover acts as a cap rock, insulating the convective regime in the Triassic sediments and the granitic basement.

Keywords: Triassic sediments; Well logging; Fracture zones; Permeability; Convection; EGS

\section{Background}

The thermal regime of the Upper Rhine Graben (URG) is characterized by a series of geothermal anomalies near Soultz-sous-Forêts (Alsace, France), Rittershoffen (Alsace, France), and Landau (Rhine-Palatinate, Germany). These areas reveal local thermal gradients up to $100^{\circ} \mathrm{C} / \mathrm{km}$ in the uppermost part of the sedimentary cover. These gradients are attributed to hydrothermal convective cells circulating inside a nearly vertical fracture network in the granite basement and in the fractured

(c) 2015 Vidal et al.; licensee Springer. This is an Open Access article distributed under the terms of the Creative Commons Attribution License (http://creativecommons.org/licenses/by/4.0), which permits unrestricted use, distribution, and reproduction in any medium, provided the original work is properly credited. 
Triassic sediments above it (Schellschmidt and Clauser 1996; Pribnow and Schellschmidt 2000; Pribnow and Clauser 2000). The interpretation of seismic reflection profiles identifies major large-scale faults extending across the Cenozoic and Mesozoic sedimentary cover and originating in the Paleozoic fractured basement (Cautru 1988) (Figure 1). Hydrothermal pathways in the sub-vertical fault network within the granitic basement are confirmed by thermo-hydraulic modeling (Le Carlier et al. 1994; Kohl et al. 2000; Baechler et al. 2003). The thermal profile of the deep Permo-Triassic sediments and the crystalline basement is dominated by a convective regime with a thermal gradient of $5^{\circ} \mathrm{C} / \mathrm{km}$. This part is characterized by the occurrence of negative thermal anomalies corresponding to zones of natural fractures (Genter et al. 2010). These cooled zones, due to drilling or stimulation operations, may be interpreted as a thermal expression of faults. However, they are not noticeable in the sedimentary cover between 0 - and 1-km depth, where the dominating thermal regime remains highly conductive. The present paper focuses on the transitional zone located between $0.8-$ and 1.2-km depth (Figure 2). This depth segment lies between the uppermost conductive zone (0- to $1.0-\mathrm{km}$ depth) and the underlying convective zone (1.0- to $3.5-\mathrm{km}$ depth).

The sediment-basement interface is clearly very attractive for industrial exploitation due to the heat carried by the geothermal fluid circulating within natural fractures. Several enhanced geothermal system (EGS) projects in the URG target geothermal reservoirs at this depth between the bottom of the sedimentary cover and the top of the granitic basement, corresponding to the top of the convective cells. For example, geothermal wells were drilled in the fractured Muschelkalk layer in Southern Germany (at Offenbach) and in Switzerland (at Riehen) to produce brine with acceptable temperatures for local energy use (Kreuter et al. 2003; Stober and Jodocy 2009; Stober and Jodocy 2011). Other projects at Cronenbourg and Rittershoffen in France and at Landau, Insheim, and Bruchsal in Germany demonstrate the quality of the resource at the fractured sediment-basement interface for geothermal uses (Housse 1984; Baumgärtner and Lerch 2013; Hettkamp et al. 2013; Villadangos 2013; Meixner et al. 2014).

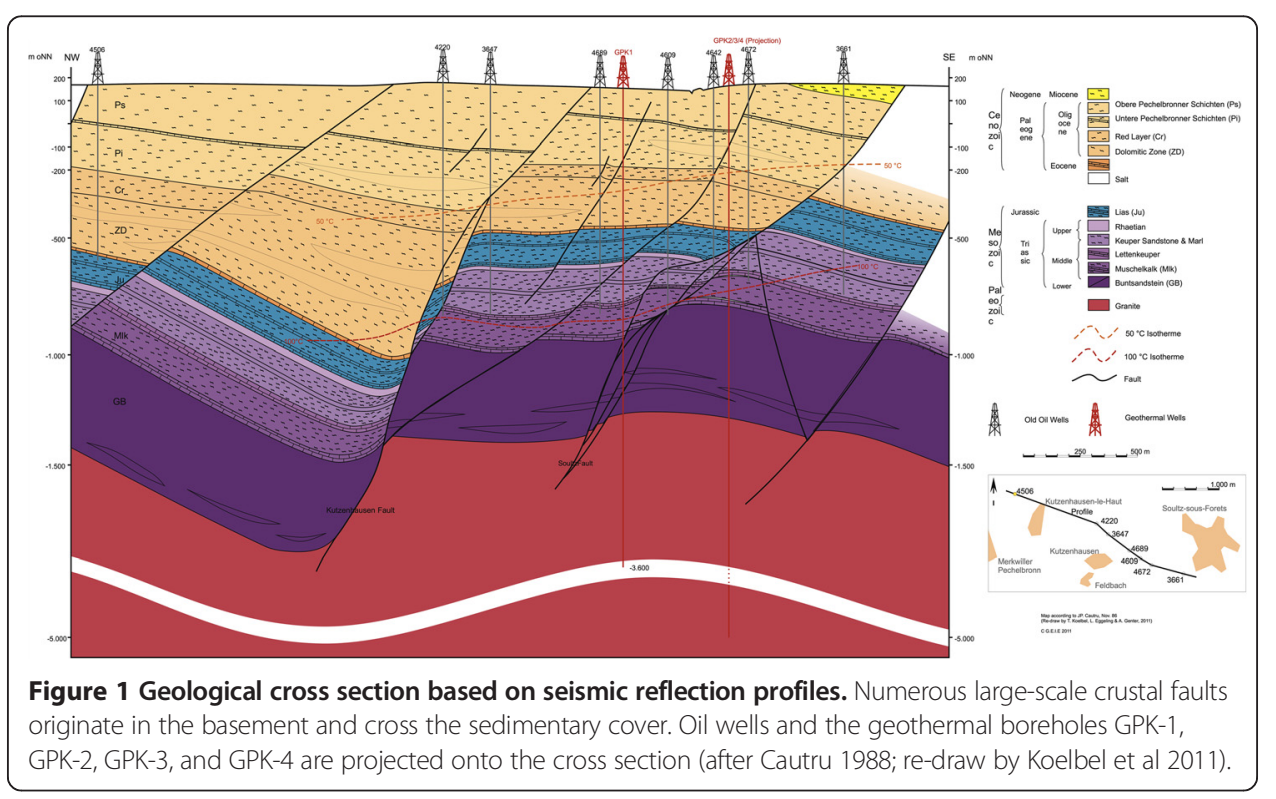




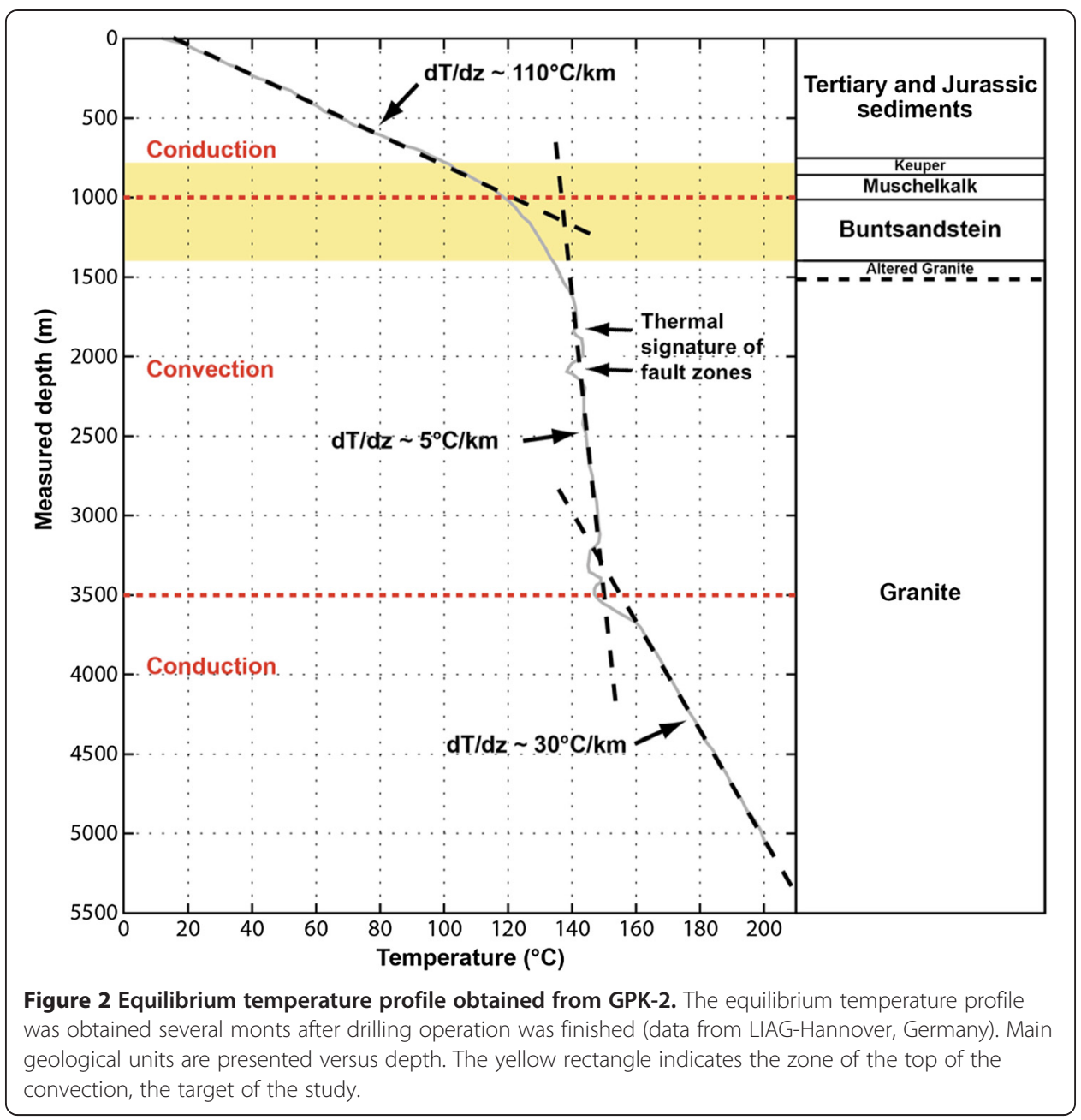

The aim of this study is to significantly contribute to a better understanding of the geological structure of the convective cells. The authors based our geological analysis of the sediment-basement interface on drilling, geological, and geophysical data available for the Soultz geothermal wells. The work concentrated on a detailed interpretation of the geophysical and geological logs from the Soultz geothermal wells GPK-1 (3.6 km), GPK-2 (5 km), GPK-3 (5 km), and GPK-4 $(5 \mathrm{~km})$, which extend mainly from the topographic surface to the Triassic formations between 0.8 - and 1.4- $\mathrm{km}$ depth. The available drilling data include the lithology, rate of penetration of the drill bit, weight on bit, evidence of natural outflow (partial and total mud losses), occurrence of gas (helium and methane), and mud temperature variations. Additional well logging data, such as temperature, gamma ray, and caliper logs, were correlated with the drilling data. The methodology was extended to peripheral wells (EPS-1 and 4550) of the Soultz field in which borehole images were available for sediments. Based on these well logging data, the location in the sedimentary cover of the fracture zones and their permeability were used to estimate the impact of the fracture system on the thermal regime. Properties of the fracture system itself limit hydrothermal circulation, and the authors tried to identify a sedimentary layer that could limit the upper part of the convective cells. Spatially 
correlating the fracture zones between different geothermal boreholes was an important focus of this study in order to explore the heterogeneity of the permeability of a given fault that crosses several wells at depth.

Following a presentation of the geothermal reservoirs at the Soultz site and a description of the geological and thermal background, the well logging data from the Soultz geothermal boreholes are evaluated to highlight fracture zones in the sedimentary cover. Then, the temperature profiles are analyzed to assess the thermal expression of fracture zones in the conductive region. Finally, a schematic conceptual model of the convective cell structure will be proposed.

\section{Presentation of the EGS site of Soultz-sous-Forêts The so-called 'Soultz geothermal anomaly'}

At the regional scale, the underground temperature distribution is spatially heterogeneous, and a series of local anomalies with temperatures above $140^{\circ} \mathrm{C}$ at $2-\mathrm{km}$ depth are mainly concentrated on the western side of the URG, such as Soultz-sous-Forêts (France), Landau (Germany), or Mainz (Germany) (Schellschmidt and Clauser 1996; Baillieux et al. 2013). The temperature anomalies in the URG are controlled by three thermally relevant mechanisms: variability in the radiogenic heat production, convection, and conduction. The so-called 'Soultz geothermal anomaly' is one of the most important temperature anomalies and has been the subject of numerous studies. Soultz granites exhibit a maximum variation in radiogenic production of 5.5 to $6.5 \mu \mathrm{W} / \mathrm{m}^{3}$ measured in core samples from GPK-1 (Rummel et al. 1988) and a more important vertical variation of 2 to $7 \mu \mathrm{W} / \mathrm{m}^{3}$ in GPK-2 (Pribnow and Schellschmidt 2000). However, this radiogenic production is insufficient to explain the geothermal anomalies (Stussi et al. 2002). Temperature data from various oil and geothermal wells reveal a concentration of hot zones along Soultz or Kutzenhausen normal faults (Benderitter and Elsass 1995; Pribnow and Clauser 2000; Pribnow and Schellschmidt 2000). These geothermal anomalies at the local scale are attributed to buoyancy-induced hydrothermal circulation within the crystalline basement and the sandstones. To explain the Soultz anomaly, various hydrothermal modeling studies have focused on the Soultz horst region (Kohl et al. 2000) and on several vertical cross sections perpendicular to the graben axis (Le Carlier et al. 1994; Person and Garven 1992; Guillou-Frottier et al. 2013).

The typical thermal profile in the 5-km-deep wells features a temperature of $200^{\circ} \mathrm{C}$ at 5 -km depth (Figure 2). The profile was measured several months after the drilling operations, and the thermal conditions are considered to be at equilibrium. This profile can be divided into three parts. The uppermost part from 0- to 1.0-km depth is composed of sedimentary formations from Tertiary and Mesozoic (Jurassic and Upper Trias) and features a geothermal gradient of $110^{\circ} \mathrm{C} / \mathrm{km}$, which indicates a conductive heat transport mechanism (Pribnow and Schellschmidt 2000). This geological section acts as a cap rock, i.e., an impermeable layer that insulates the hydrothermal system active below.

The part from 1.0- to $3.5-\mathrm{km}$ depth is composed of deep sedimentary formations (Buntsandstein and Permian sandstones) and granitic basement and features a very low geothermal gradient of $5^{\circ} \mathrm{C} / \mathrm{km}$, which indicates the presence of a convection process. This second thermal unit is locally disturbed by cold fractured zones, for example at $1.6-\mathrm{km}$ depth or $2.1-\mathrm{km}$ depth, which can be interpreted as the remnants of 
formation cooling induced by drilling and from massive hydraulic injections (Genter et al. 2010). Permeable fractured and altered zones are cooled by the invasion of drilling mud or fresh water during hydraulic stimulation operations. Fractures in the granitic basement have a negative thermal signature visible even several months after hydraulic operations.

Finally, the deepest part of the profile, greater than $3.5-\mathrm{km}$ depth, is composed only of crystalline formations and features a linear gradient of approximately $30^{\circ} \mathrm{C} / \mathrm{km}$, indicating a return to a conduction-dominated regime.

\section{Soultz reservoirs}

The target of the Soultz project was the development, the hydraulic testing, and the modeling of two EGS heat exchangers developed within the granitic basement at depths of 3.5- and 5-km depth (Gérard et al. 2006; Dezayes et al. 2010). The different phases of the Soultz project have provided a rich and diverse database on the granitic basement (Figure 3). However, knowledge of the $1.4 \mathrm{~km}$ of overlying Cenozoic and Mesozoic sediments is much poorer. Despite intensive investigations in the uppermost depth range during the oil production of the Merkwiller-Pechelbronn oil field, geothermal exploration has focused on the granitic basement. Four geothermal boreholes were drilled into the crystalline basement: GPK-1, GPK-2, GPK-3, and GPK-4 (Figure 3). Geothermal water is pumped from the production well (GPK-2) and re-injected at lower temperatures into the injection wells (GPK-3 and GPK-4) after delivering geothermal energy through a heat exchanger to a binary power plant (Genter et al. 2013). At Soultz, three other proximal wells penetrated the granitic basement and thus its sedimentary cover, and these wells provided extra information. These additional wells include the pilot geothermal borehole GPK-1; EPS-1, a renamed former petroleum well that has been deepened to $2.2-\mathrm{km}$ depth and fully cored for use as an exploration well,

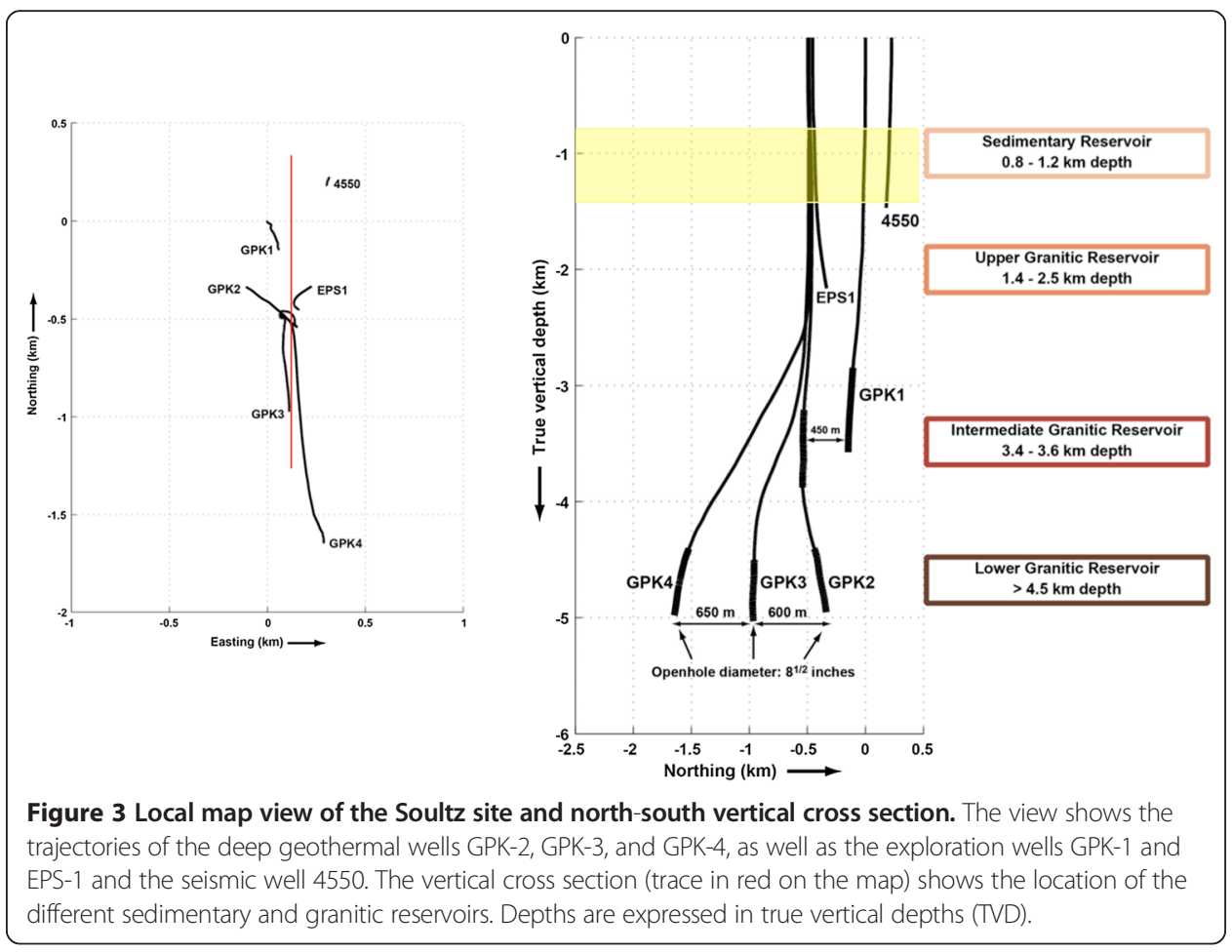


and another former petroleum well 4550 that has been extended to $1.5-\mathrm{km}$ depth and used as a micro-seismic monitoring well (Degouy et al. 1992).

Below the sediments, the crystalline basement is encountered at $1.4-$ to $5.0-\mathrm{km}$ depth (Figure 1) and exhibits several indications of convection associated with the fracture system that ranges from micro-cracks to local faults. From core analyses and interpretations of well logs, natural fractures within the granite are thought to be clustered in hydrothermally altered and fractured zones (Genter et al. 2000). Moreover, the natural fracture system directly controls the zones that produce geothermal fluid and the zones of drilling mud loss (Vuataz et al. 1990; Evans et al. 2005). Strong hydrothermal alteration is evidence of paleo-circulation, which has resulted in the dissolution of primary minerals, such as biotite and plagioclase (Genter 1989; Genter et al. 2000). However, fracture zones present both permeability and sealing related to the deposition of hydrothermal minerals, such as secondary quartz, clay minerals, calcite, and sulfides (Genter and Traineau 1992; Genter and Traineau 1996; Genter et al. 1997) (Figure 4). Traces of organic matter in a fracture zone from EPS-1 reveal hydraulic communication between the basement and sediments (Ledésert et al. 1996).

A detailed analysis of image logs, standard geophysical logs, petrographic logs, and flow logs reveals a clear spatial relationship between the occurrence of natural permeability and hydrothermally altered and fractured zones in the granite (Evans et al. 2005; Dezayes et al. 2010). Natural brine circulates within a sub-vertical fracture system between the deepest crystalline water-bearing zones and those in the lower sedimentary layers. This paper focuses on a detailed analysis of various borehole data (mud logging and geophysical logs) from the formations between 0.8 - and 1.2-km depth.

\section{Geology of the sedimentary cover}

In GPK-2, the Tertiary sediments extend from the topographic surface down to 623-m depth. The uppermost part is composed of clays and marls in the Pechelbronn oil formations of Oligocene age (316-m depth) (Ménillet 1976; Cautru 1988) (Figure 1). The Eocene formations are divided into two types of marl: the ferruginous marlstones of the Red Layer (353-m depth) and the marlstones interbedded with dolomite layers of the Dolomitic Zone (601-m depth). At its base, there is a thin layer of dark claystones dated to the late Eocene. This Tertiary section features an erosional contact with the Jurassic formations. The Dogger formations are dark-grey clays with calcareous shale (653-m depth), and the Lias formations are grey silty calcareous claystones (763-m depth). The lowest part of the sedimentary cover is a typical Germanic Triassic sequence with Upper Triassic dolomites, anhydrite and clays for layers: the Keuper formation extends down to 853-m depth and the Lettenkohle formation down to 873-m depth. The stratigraphy of the Muschelkalk and Buntsandstein can be specified thanks to core samples from EPS-1. The stratigraphic series of the typical Germanic Triassic sequence indicates rather constant thicknesses through all the URG, and all formations can be easily correlated between boreholes, even if separated by several kilometers. The top of the Upper Muschelkalk is composed of massive limestones rich in Terebratula over marly calcareous formations that extend over $35 \mathrm{~m}$ before giving way to massive crinoidal limestone beds. These high carbonate content limestone beds are the most competent rocks of the sedimentary cover. They are approximately 14-m thick and mark the transition to the Middle Muschelkalk. The central section of the Muschelkalk is composed of marly dolomites invaded by 


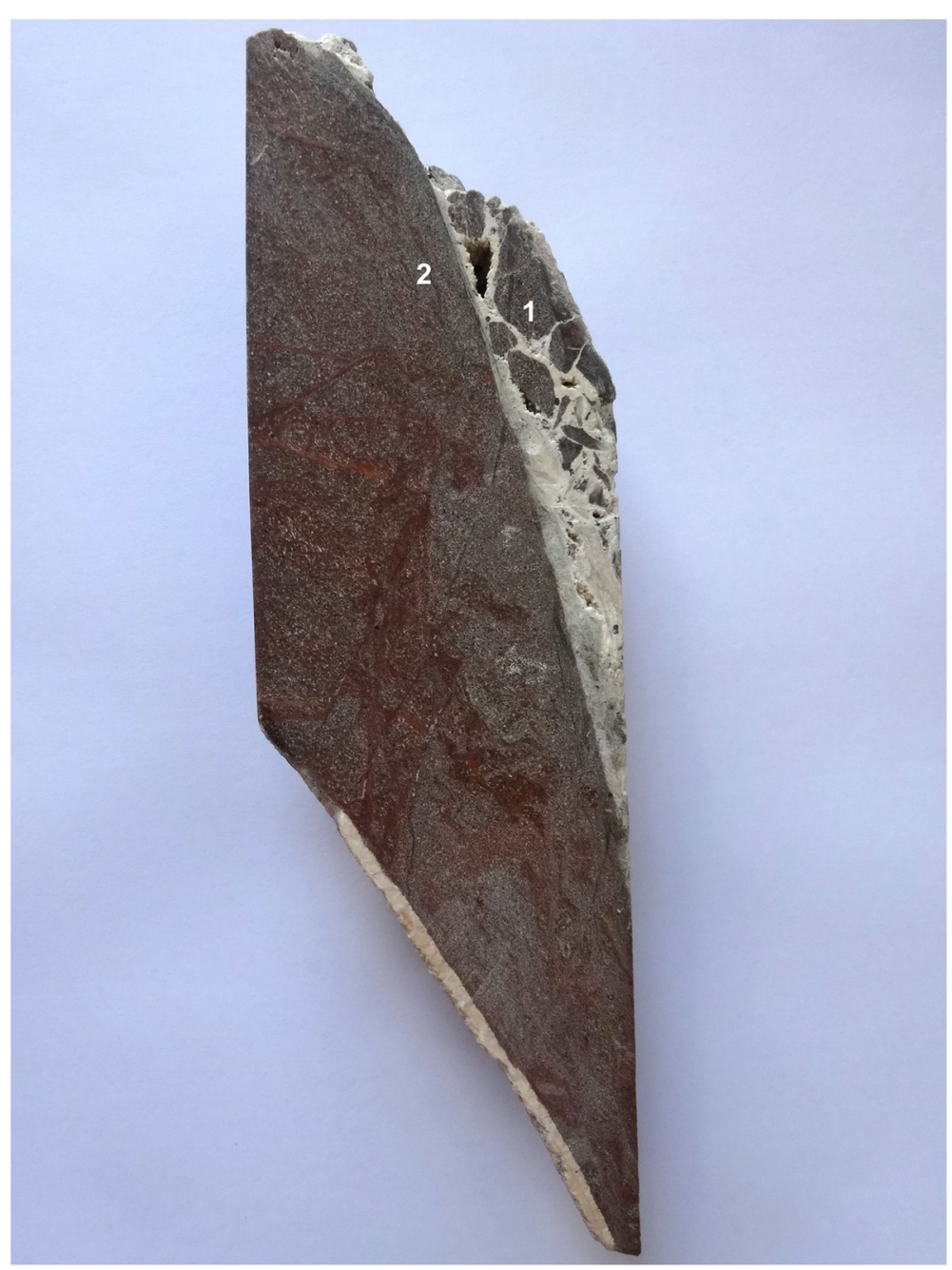

Figure 4 Core sample from a sandstone in the Buntsandstein at 1,204-m depth in the well EPS-1. The core sample exhibits a part of a fracture zone (1) and its damage zone (2). Barite and galena fill the hydraulic breccia. The diameter of the core sample is $8 \mathrm{~cm}$.

anhydrite (circa 50-m thick). The Upper Muschelkalk begins at a depth of approximately $980 \mathrm{~m}$ and is divided into two parts: the upper part is marly calcareous dolomites and the lower part is fossil-rich sandstones to a depth of $1,021 \mathrm{~m}$. The sedimentary cover ends with the Buntsandstein sandstones that extend to a depth of 1,405 m. At the top of the formation, the Voltzia sandstones are fine-grained sandstones with interbedded clays and are over 10-m thick. The so-called Intermediate Layers are sandstones with a larger grain size and are approximately 40-m thick. The Middle Buntsandstein is represented by the Vosgian sandstones, typical medium-grained to conglomeratic continental sandstones with clay formations. The last $50 \mathrm{~m}$ of the formation is composed of the Annweiler sandstones, an argillaceous red sandstone. The transitional layer of Permian sandstones is visible in core samples from the EPS-1 well but hardly distinguishable in cuttings. The evaluated porosity of the Buntsandstein is quite low (10\% at the top of the formation and $20 \%$ for the Vosgian sandstones) (Vernoux et al. 1995). Petrophysical studies of the core samples note the role of the matrix permeability, which controls the geothermal fluid circulation through these sandstones (Haffen et al. 2013). 


\section{Methods}

\section{Fracture zone definition}

The authors conducted a comprehensive borehole data analysis of the Soultz geothermal boreholes. The data collected during the drilling operations included drilling mud losses, natural outflow, gas content, and the rate of penetration (ROP). Geophysical well logs, such as caliper, gamma ray (GR), bulk density, neutron porosity, and borehole wall images, were used and compared to the mud logging data. The depth match interval of $-4 \mathrm{~m}$ between the drilling mud logging data and the geophysical well logging data must be taken into account. To avoid moving these data sets artificially upward or downward, it was decided to leave the data in their own separate depth reference frames.

Because the Soultz geothermal project mainly focused on deep crystalline reservoirs, only a few of the geophysical well logs have been collected properly. For example, the GR and caliper logs were systematically collected in all the geothermal wells, whereas the bulk density, neutron porosity, and image logs were less frequently collected.

For GPK-2, GPK-3, GPK-4, EPS-1, and 4550, the temperature logs were obtained behind the casing at thermal equilibrium conditions, whereas for GPK-1, one temperature log was obtained just a few hours after the end of drilling operations.

For each geothermal well, the available borehole data were correlated spatially with depth to highlight any physical variations that might be interpreted as indication of fracture zones. Three types of fracture zones have been outlined:

- A permeable fracture zone is defined by the occurrence of drilling mud losses, natural outflow, or helium gas content. The best permeability indicator during drilling operations is total mud loss. Generally, in such conditions, calipers and ROP increase simultaneously at the same depth.

- A sealed fracture zone is defined by absence of obvious mud losses or natural outflow. However, a fracture zone can be defined by caliper enlargement, porosity increase, ROP increase, or bulk density decrease.

- A partially sealed fracture zone possesses an intermediate set of properties between a permeable and a sealed fracture zone. In some cases, there is a clear indication of fracture zone occurrence (caliper or ROP increases), but permeable indicators are poorly constrained. For example, mud logging data are mainly qualitative, and this fact introduces a certain amount of uncertainty to the permeability range. Very small temperature variations are also a criterion, which might cause a given fracture zone to be re-qualified as only partially permeable.

Fracture geometry has been evaluated only in EPS-1 and 4550 in certain localized fracture zones where image logs were available. Thus, this methodology has only been applied to data collected from boreholes drilled specifically for exploration and research.

\section{Typology of the data}

Even if sedimentary cover was not the main target of the geothermal exploration at Soultz, a series of well logs has been collected from the geothermal wells (GPK-2, GPK3 , and GPK-4), the exploration wells (GPK-1 and EPS-1), and one of the micro-seismic monitoring wells (4550). 
The first group of well logging data consists of instantaneous well logs, such as the ROP, which records the speed at which the drill bit penetrates the rock, usually reported in $\mathrm{m} / \mathrm{h}$. Normally, the speed of the drill bit decreases as the drill bit bores into denser formations. At Soultz, the mean speed is $8 \mathrm{~m} / \mathrm{h}$ in soft sediments (above $1-\mathrm{km}$ depth), $5 \mathrm{~m} / \mathrm{h}$ in hard sediments (below 1-km depth) and just $2 \mathrm{~m} / \mathrm{h}$ in the granite. When the ROP is higher than the mean value, the occurrence is generally interpreted as the effect of a localized fracture zone. In such a case, the driller is obliged to reduce the weight on the bit (WOB) to drill in stable drilling conditions. The WOB is the mass of the tool string that applies a vertical load on the drill bit and ranges, in the Soultz case, from 11 tons in soft sediments to 15 tons in hard Triassic sediments or granite. If the WOB is reduced by the driller, the ROP is artificially low but could nevertheless indicate a fracture zone.

Flow variations represent the amount of mud circulation and can be interpreted as a loss (outflow). Mud, also called drilling fluid, refers to fluids that contain a significant proportion of suspended solids in aqueous solution. When the drill bit crosses a permeable fracture zone, the well records a partial decrease in the outflow or even a total loss of mud circulation. Variations in the mud temperature, recorded in degrees Celsius, suggest mixing between hot geothermal fluid and cold drilling mud. As is the case for a natural outflow, the permeable fractures bearing hot fluid could induce drastic variations in the drilling mud temperature.

Mud logging also includes the monitoring of natural gas emissions. This classic method for fracture zone detection has already been demonstrated at Soultz, where helium gas anomalies are associated with permeable fractures at 1,810-m depth in the granite part of GPK-1 (Vuataz et al. 1990). A content of hydrocarbon gas, such as methane, could be interpreted as indicating fluid circulation in local fracture zones or as an indicator of matrix permeability. For reference, the contents of helium, methane, and ethane in the atmosphere are approximately $5.24 \mathrm{ppm}, 1.75 \mathrm{ppm}$, and $0.50 \mathrm{ppm}$, respectively.

The second group of well logging data consists of wireline logs, measured continuously while the tool is pulled upward from the bottom of the borehole. The measurements are transmitted continuously via the wireline to the surface. For this study, standard geophysical wireline logs were used to measure the gamma ray of natural radioactivity in the geological formations in the borehole and reported in gAPI. At Soultz, the spectral gamma ray measurement was a significant proof of hydrothermally altered and fractured zones in the granite (Hooijkaas et al. 2006). It is more difficult to use this method to identify fracture zones in Triassic sediments due to their lower content of radioisotopes. In the Lettenkohle and the Upper Muschelkalk, the local GR minima are associated with the marly calcareous formations. In the Buntsandstein, clay layers (less than $2 \mathrm{~m}$ thick) correspond to isolated and localized GR peaks. Peaks associated with fracture zones with hydrothermal alteration halos show a larger GR variation than those induced by sedimentary clay layers.

In a fracture zone, the caliper no longer measures a simple cylindrical borehole diameter. The drillhole is no longer circular but rather resembles a 'cave'. The borehole image log, also called the BoreHole TeleViewer (BHTV) log, is very useful in evaluating the fracture geometry. If the fracture is visible in both the amplitude and transit time data, the fracture is open at least on the borehole scale. If fractures are visible in the 
amplitude data but not in the transit time data, the fractures are sealed by mineral deposition. Because these tools are oriented according to the magnetic North, stratification or fracture geometry (dip and dip direction) can be estimated with the borehole image logs. In the Soultz wells, BHTV logs in the depth ranges of interest here were only available in sandstones from the Buntsandstein in EPS-1 and 4550.

Other standard geophysical measurements, such as the bulk density of the rock formation (recorded in $\mathrm{g} / \mathrm{cm}^{3}$ ), neutron porosity (measured in percent), or resistivity (expressed in $\mathrm{ohm} / \mathrm{m}$ ), are commonly used to characterize fracture zones and were already widely available from Soultz granite (Genter and Traineau 1992).

\section{Fracture zone location in the wells}

Fracture zone locations were first evaluated in the wells GPK-2, GPK-3, and GPK-4 from mud logging, calipers, and GR data (Baumgärtner et al. 1995; Baumgärtner et al. 2000; Baumgärtner et al. 2005; Hettkamp et al. 2004). Because the wellheads are very close (less than $15 \mathrm{~m}$ apart) and because the wells are sub-vertical in the same sedimentary section, we spatially correlated certain fracture zones. To compare the fracture zones in the wells, a similar terminology and labeling for fracture zones has been used for the three geothermal wells. A given fracture zone is not necessarily visible in all the wells.

Fracture zone locations have also been investigated in the pilot geothermal/exploration borehole GPK-1, the exploration/research well EPS-1, and the micro-seismic monitoring well 4550 (Degouy et al. 1992). In GPK-1, the density, porosity, GR, and resistivity logs were available (Herbrich 1988). Additional geophysical measurements, such as BHTV, were available for EPS-1 and 4550, and continuous core samples collected in EPS-1 have proved to be very useful for correlating mud losses with depth.

In this analysis, a fracture zone could be defined as a steeply dipping single fracture. It is clearly visible on caliper data or BHTV logs when available. However, a fracture zone is generally a rather complex geometric structure composed of several individual fractures, spatially concentrated within a cluster. When BHTV logs are also available, a fracture zone is easily interpreted in terms of geometry and depth location. With standard geophysical logs, such as that obtained with a six-arm caliper, several individual peaks visible on each curve are very helpful in characterizing a given fracture zone (Figure 5, zone 1). In some cases, the depth of an ROP increase agrees with a caliper enlargement, reinforcing indications of the presence of a fracture zone.

\section{Results and discussion}

Characterization of the fracture zones in the wells

Well GPK-2

The synthetic log of GPK-2 shown in Figure 5 contains lithology, stratigraphy, GR, and caliper data. The caliper was a three-arm tool with three diameters that correspond to C14, C25, and C36 data. The nominal diameter of the well is 12.25 inches when the wellbore is not affected by caving or ovalization. ROP is locally absent because digital data were only available for the granite section. The log in Figure 5 also presents two permeability indicators: mud losses and helium or methane enrichment. 


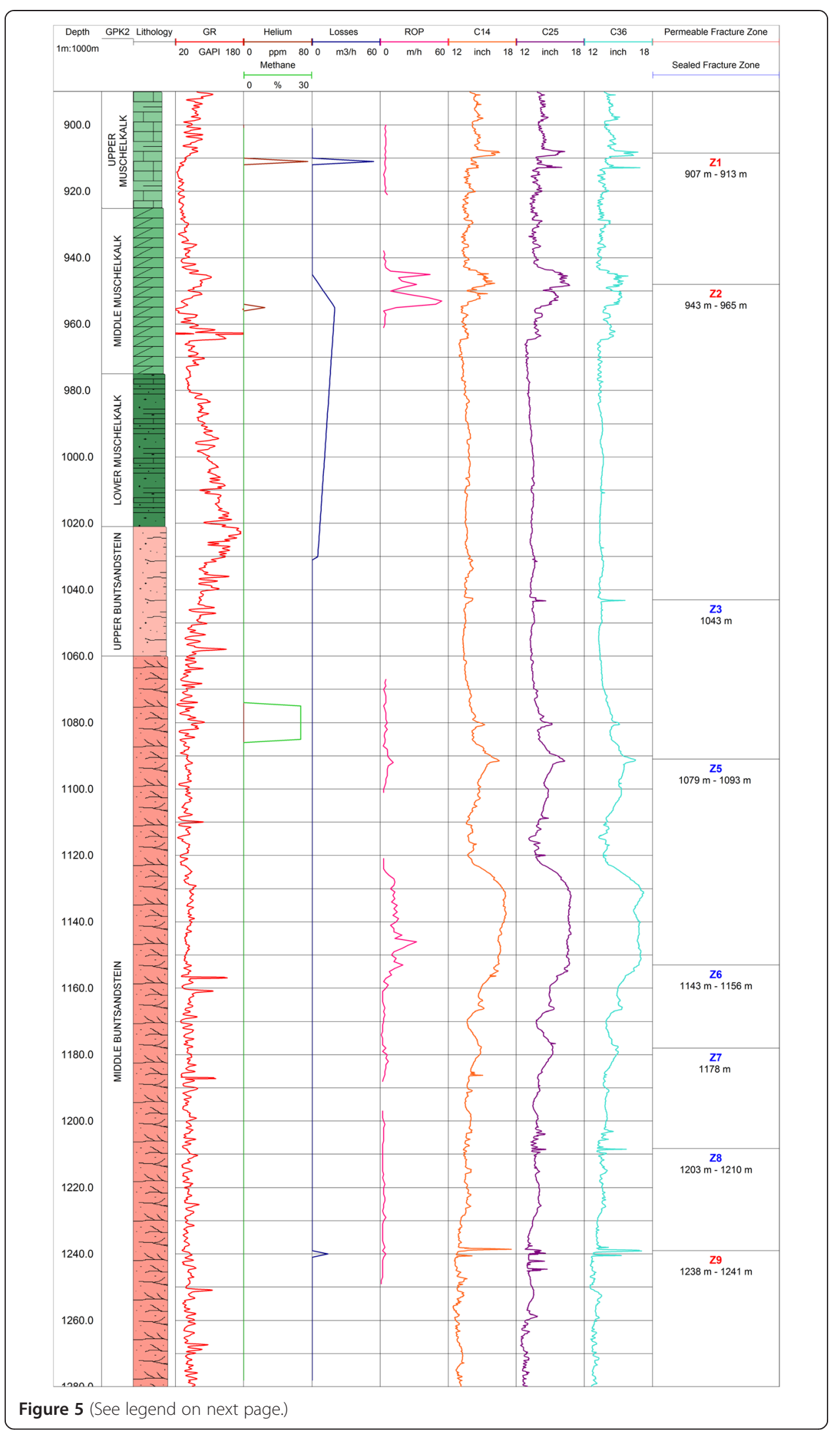


(See figure on previous page.)

Figure 5 Synthetic log of GPK-2. The synthetic log shows the lithology, mud losses, GR, gas occurrences (helium and methane), ROP, and caliper (C14, C25, C36) data. Fracture zones are indicated: Z1, Z2, Z3, Z5, Z6, Z7, Z8, and Z9. Permeable zones are in red and sealed zones are in blue. Depths are expressed in measured depth.

The depth range covered by the synthetic log was focused on the sedimentary part, where permeability indicators were detected, for example between the 890- and 1,280$m$ depth (Figure 5). In this depth section, eight fracture zones have been highlighted from well logging data. Zones Z1, Z2, and Z9 are deduced from mud loss information and helium emissions correlated spatially with local caliper enlargement. Zones Z3, Z5, Z6, Z7, and Z8 are hypothesized from local caliper or ROP variations. Thus, they are interpreted as sealed fractures or fracture zones with no indications of permeability during drilling.

Zone $\mathrm{Z} 1$ is permeable and featured total mud loss. Several individual peaks are visible in the caliper data from 907 - and 913-m depth, with a maximum of 16.60 inches for C36 at 908-m depth. Because of the nominal diameter of 12.25 inches at this depth, the well diameter is wider by 4.45 inches in zone Z1. Helium concentrations reach $73 \mathrm{ppm}$ at 911-m depth, which is 14 times higher than the atmospheric helium value. Zone Z1 clearly shows the depth match of circa $-4 \mathrm{~m}$ between the drilling mud logging data and the geophysical well logging data (Figure 5). The helium peak visible at $911 \mathrm{~m}$ fits with the caliper anomaly visible at $908-\mathrm{m}$ depth. Surprisingly, the ROP is stable. Zone Z1 is a complex permeable fracture zone.

Zone Z2 is a complex structure extending vertically from 943- to $965-\mathrm{m}$ depth. The caliper data indicate a large perturbation zone with a maximum C25 diameter of 16.60 inches at $948 \mathrm{~m}$, an enlargement of 4.45 inches. The ROP values are higher than $50 \mathrm{~m} / \mathrm{h}$ at 953-m depth and fit spatially with helium concentrations of $25 \mathrm{ppm}$. Persistent mud losses are recorded between $955 \mathrm{~m}\left(20 \mathrm{~m}^{3} / \mathrm{h}\right)$ and $1,030 \mathrm{~m}\left(5 \mathrm{~m}^{3} / \mathrm{h}\right)$. The relatively high GR values (104.34 gAPI and 223.25 gAPI at depths of $945 \mathrm{~m}$ and $963 \mathrm{~m}$, respectively) are interpreted as a brecciated fault zone filled with clays in the Middle Muschelkalk. Hence, zone Z2 is a complex fracture zone with obvious permeability indicators.

Caliper variations in zone $\mathrm{Z} 3$ are very local, featuring a sharp peak on three calipers with a maximum of 15.56 inches for C36 at 1,043-m depth. This fracture zone is a single, non-permeable fracture.

Zone Z4 is not visible on GPK-2 but is visible in GPK-3 and GPK-4.

Zone Z5 is characterized by noticeable positive anomalies on the three caliper curves between 1,079- and 1,093-m depth. The maximum caliper variation of 16.18 inches for C25 at $1,091 \mathrm{~m}$ fits with a ROP positive anomaly of $11.50 \mathrm{~m} / \mathrm{h}$ at $1,092 \mathrm{~m}$. A depth interval stretching from 1,075 to $1,089 \mathrm{~m}$ features a substantial methane content. Because the methane variation is larger than the discrete caliper peaks, the methane could be related to the presence of organic compounds in the matrix sandstones. Thus, zone Z5 corresponds to a sealed complex fracture zone.

Caliper variations in zone Z6 extend from 1,143- to 1,156-m depth. This zone represents the greatest enlargement found in the sedimentary part of GPK-2 (5.25 inches at 1,130-m depth). It is most likely related to the lithologic nature of the formations. The ROP positive 
anomaly features a maximum of $32.40 \mathrm{~m} / \mathrm{h}$ at $1,146-\mathrm{m}$ depth. Because there is no evidence of mud loss or helium anomalies, zone Z6 is classified as a sealed fracture zone.

Zone Z7 features a caliper variation in all three curves. For C25, a maximum of 15.46 inches occurs at $1,176-\mathrm{m}$ depth. There is no anomaly in the mud logging data; hence, zone $\mathrm{Z7}$ is an individual sealed fracture.

Zone $\mathrm{Z} 8$ is considered as complex because calipers present several individual peaks between 1,203- and 1,210-m depth. As in the case of Z7, there is no evidence of permeability indicators; thus, $\mathrm{Z} 8$ has been interpreted as a complex sealed fracture zone.

The last zone, Z9, is characterized by mud losses of $14 \mathrm{~m}^{3} / \mathrm{h}$ recorded at a depth of $1,240 \mathrm{~m}$. The caliper values match the depths of several peaks and a major anomaly of 16.80 inches at 1,238-m depth. Zone Z9 is therefore classified as a complex permeable fracture zone.

\section{Well GPK-3}

The synthetic log of GPK-3 presented in Figure 6 contains lithology, GR, ROP, natural inflow and outflow, temperature inflow and outflow, and six-arm caliper (radii RD1 to RD6) data. Between 890- and 1,280-m depth, the nominal diameter is 17.50 inches. For GPK-3, helium and methane surveys were performed only in the granitic section of the well, i.e., below $2-\mathrm{km}$ depth. Mud loss data come from daily drilling reports from Socomine (dark blue curve) and from Hettkamp et al. (2004) (light blue section).

Zones Z1, Z2, Z4, and Z9 have been highlighted by mud losses recorded by the drilling company. Zones Z3, Z6, Z7, and Z8 are based on significant variations in at least two well log parameters (Figure 6).

In GPK-3, mud losses are observed at 904-m depth. Zone Z1 features a series of caliper variations visible on the six radii recorded by the six-arm tool between 894- and 914-m depth and is characterized by a clear positive anomaly visible in the ROP data (11.77 $\mathrm{m} / \mathrm{h}$ at $914-\mathrm{m}$ depth). $\mathrm{Z} 1$ is interpreted as a complex permeable fracture zone.

Zone $\mathrm{Z} 2$ is a complex structure with several positive anomalies visible in the ROP curve with a maximum of $42.52 \mathrm{~m} / \mathrm{h}$ at $950 \mathrm{~m}$, which correlates with mud losses of approximately $32.40 \mathrm{~m}^{3} / \mathrm{h}$ at the same depth. The GR value of $98.97 \mathrm{gAPI}$ at $950-\mathrm{m}$ depth is an additional indication of a fracture zone with clay deposition. The caliper data also feature the values 13.94 inches for RD4 at 951-m depth and 13.18 inches for RD5 at 952-m depth. These values correspond to a diameter of 24.60 inches, thus an enlargement of 7.10 inches. As mud losses are observed, $\mathrm{Z} 2$ is classed as a complex permeable fracture zone.

Zone Z3 features a sharp positive variation in caliper data, with values of 10.35 inches for RD1, 11.52 inches for RD2, and 9.22 inches for RD3 at a depth of 1,049 m. Zone Z3 is a sealed individual fracture.

Zone Z4 represents a small variation in the caliper data (11.22 inches at 1,066 m on RD1) and in the ROP data $(6.68 \mathrm{~m} / \mathrm{h}$ at $1,072 \mathrm{~m})$. $\mathrm{Z} 4$ features several permeability indicators from the mud logging. Mud losses of $3 \mathrm{~m}^{3} / \mathrm{h}$ are recorded at 1,067-m depth. Clear evidence from the mud logging data have led to $\mathrm{Z} 4$ being interpreted as a permeable single fracture.

Zone Z5 is not clearly visible in GPK-3.

Zone Z6 is characterized by several positive variations visible from the readings of the six-arm caliper between 1,146- and 1,154-m depth. The maximum of caliper anomaly is 11.62 inches for RD4 at 1,152-m depth. The ROP also presents several positive variations, with a maximum of $15.17 \mathrm{~m} / \mathrm{h}$ at 1,148-m depth. Zone Z6 is a sealed fracture zone. 


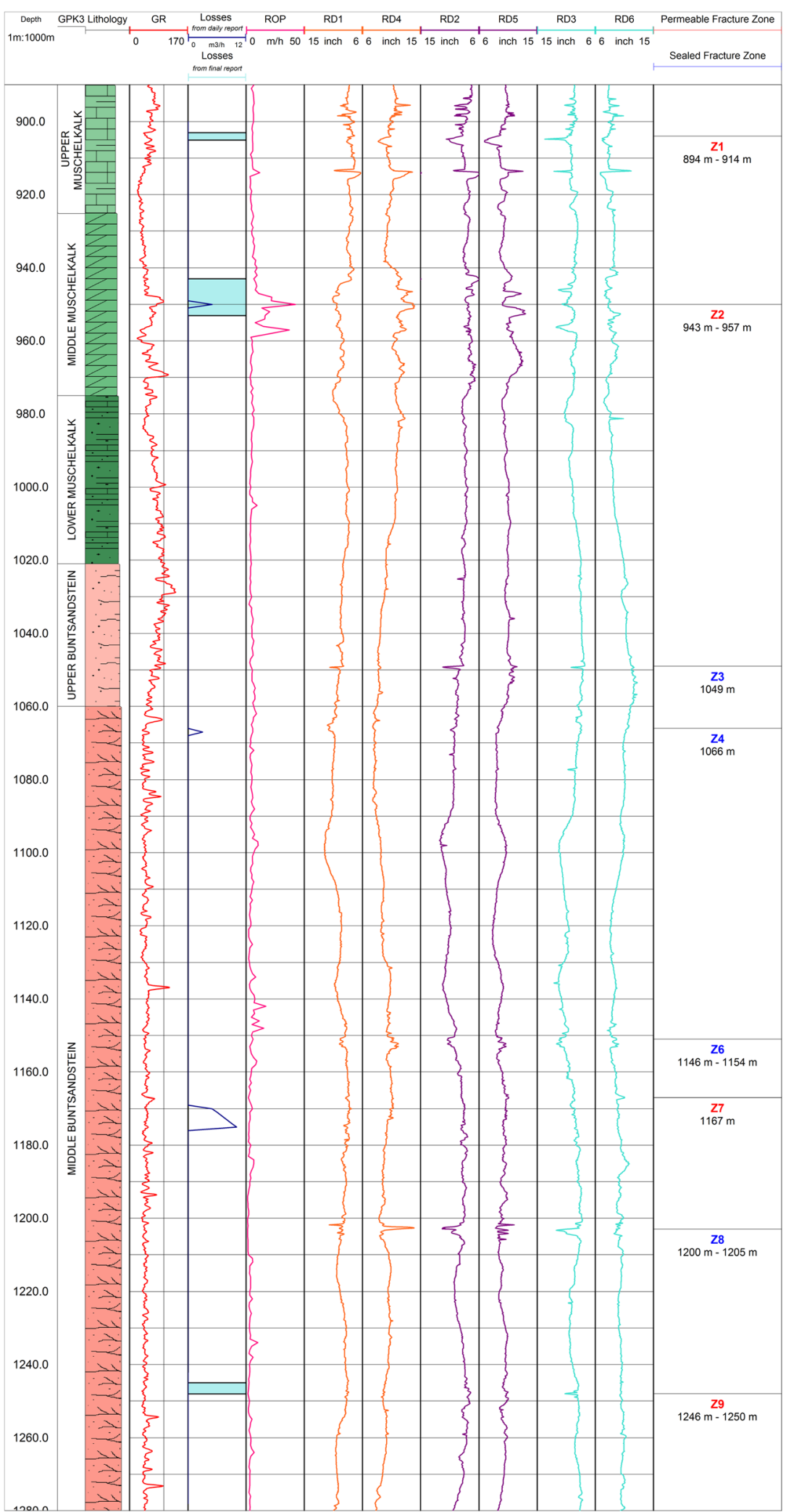

Figure 6 (See legend on next page.) 
(See figure on previous page.)

Figure 6 Synthetic log of GPK-3. The synthetic log shows mud losses from daily report (dark blue curve) and from Hettkamp et al. (2004) (light blue section), GR, ROP and caliper (RD1, RD2, RD3, RD4, RD5, RD6) data. The lithology is the same as GPK-2. Fracture zones are indicated: Z1, Z2, Z3, Z4, Z6, Z7, Z8, and Z9. Permeable zones are in red and sealed zones are in blue. Depths are expressed in measured depth.

Zone Z7 is characterized by variations in both the caliper data (10.50 inches at 1,167-m depth) and ROP data (5.38 m/h at 1,169-m depth). Mud losses of $5 \mathrm{~m}^{3} / \mathrm{h}$ are observed at $1,169-\mathrm{m}$ depth and increase to $10 \mathrm{~m}^{3} / \mathrm{h}$ at $1,175 \mathrm{~m}$. Zone $\mathrm{Z} 7$ is a permeable fracture.

Zone Z8 is visible on the radius readings of the six-arm caliper (13.94 inches for RD4 at $1,202-\mathrm{m}$ depth). The ROP is constant, but this fact could be explained by the zero WOB at this depth. Zone Z8 is a complex sealed fracture zone with a vertical extent from 1,200 - to $1,205-\mathrm{m}$ depth.

Zone Z9 is characterized by mud losses at 1,245-m depth and caliper variations, with a maximum of 10.84 inches at $1,248-\mathrm{m}$ depth. Surprisingly, the ROP is flat. Z9 is a permeable fracture zone extending vertically from 1,246- down to 1,250 -m depth.

\section{Well GPK-4}

The synthetic log of GPK-4 in Figure 7 presents lithology and ROP data, as well as methane and ethane occurrences monitored by the driller and a service company in the sedimentary part of the well. The caliper and GR data were collected between the surface and the top of the basement. The caliper was a two-orthogonal-arms tool with two measurements, CAL1 and CAL2. The nominal diameter between 890- and 1,280-m depth was 17.50 inches.

As was the case for GPK-2 and GPK-3, it was possible to correlate zone Z2 in GPK-4 due to the mud loss data. Zones Z4, Z6, and Z9 are thought to be present due to significant variation in at least two well logging data sets (Figure 7).

Zone $\mathrm{Z} 1$ is not visible in GPK-4.

Zone $\mathrm{Z2}$ is a complex structure with several peaks visible between 945 - and 957-m depth in the ROP data (124.86 m/h at 954-m depth) and caliper data (21.91 inches on CAL2 at 952-m depth). Zone Z2 is permeable because $4 \mathrm{~m}^{3} / \mathrm{h}$ losses were recorded between $956-\mathrm{m}$ and 1,012-m depth. The clear shift to 80.30 gAPI in the GR curve from $948-$ to $955-\mathrm{m}$ depth is also a permeability indication. $\mathrm{Z} 2$ is a complex permeable fracture zone.

Zone $\mathrm{Z3}$ is not visible in GPK-4.

In zone $\mathrm{Z} 4$, caliper readings show a moderate variation to 18.87 inches at 1,069-m depth, the outflow data feature a strong negative anomaly with a total loss at 1,069-m depth. At 1,066-m depth, the ROP value reaches $43.17 \mathrm{~m} / \mathrm{h}$, even when the WOB is reduced to 5.30 tons at the same depth. At a depth of $1,065 \mathrm{~m}$, mud outflow becomes zero, suggesting a loss of mud in a permeable structure, but this information is of uncertain value because the mud inflow data are missing. Gas contents increase to $72.13 \mathrm{ppm}$ for methane and to $11.12 \mathrm{ppm}$ for ethane, both at 1,069-m depth. However, it is rather difficult to attribute this gas content increase to fracture permeability and not to matrix permeability. Z4 is therefore classified as a partly sealed fracture.

Zone $\mathrm{Z} 5$ is not visible on GPK-4.

Zone Z6 is characterized by several anomalies between 1,138- and 1,155-m depth. These anomalies affect the caliper data (18.69 inches for CAL2 at 1,141-m depth) and 


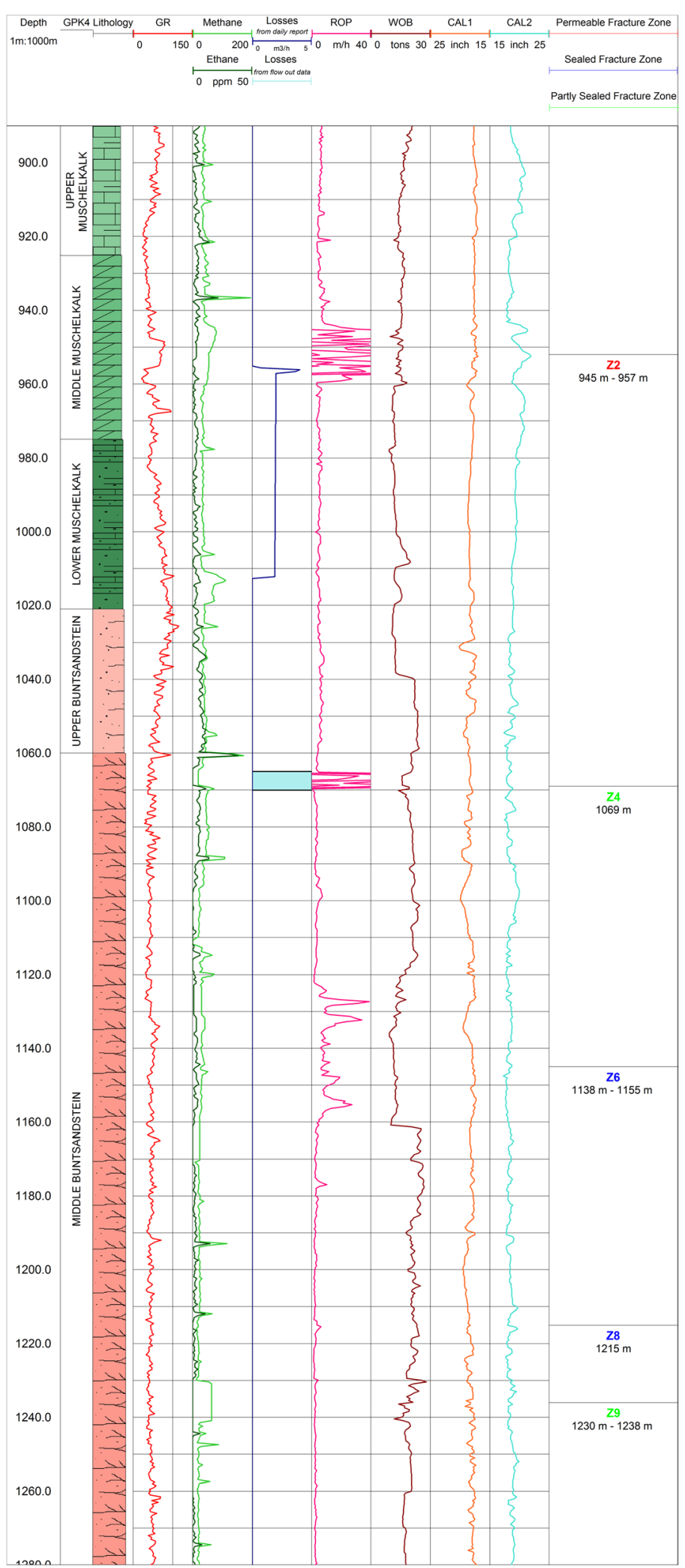

Figure 7 (See legend on next page.) 
(See figure on previous page.)

Figure 7 Synthetic log of GPK-4. The synthetic log shows mud losses from daily report (dark blue curve) and from outflow data (light blue section), GR, occurrences of gas (methane and ethane), ROP, and caliper (CAL1 and CAL2) data. The lithology is the same as GPK-2. Fracture zones are indicated: Z2, Z4, Z6, Z8, and Z9. Permeable zones are in red, partly sealed zones are in green and sealed zones are in blue. Depths are expressed in measured depth.

ROP data $(18.99 \mathrm{~m} / \mathrm{h}$ at $1,147-\mathrm{m}$ depth). The temperature data also display large variations in the same depth section. Zone Z6 is a complex sealed fracture zone.

Zone $\mathrm{Z7}$ is not noticeable on GPK-4.

Zone Z8 is apparent at 1,215-m depth with a CAL2 value of 19.66 inches and a positive ROP anomaly of $6.37 \mathrm{~m} / \mathrm{h}$ at the same depth. Because there are no significant variations in the mud logging, Z8 is interpreted as a sealed, localized fracture.

Zone Z9 features a slight caliper enlargement between 1,230- and 1,238-m depth, with a maximum of 19.47 inches for CAL2 at 1,233-m depth. The ROP is abnormally flat in this depth range. The methane curve exhibits a large jump of 100 ppm, suggesting some permeability. Zone Z9 is a partly sealed fracture zone.

\section{Well GPK-1}

For GPK-1, the lithology is slightly different from that for GPK-2, GPK-3, and GPK-4 because its wellhead is located approximately $450 \mathrm{~m}$ to the North of the deeper triplet (Figure 3). The correlation of fracture zones between GPK-1 and the other geothermal wells is not possible in this 1D study; thus, the labeling of fracture zones is different for GPK-1. Mud logging data are composed of descriptions of cuttings composition, spot coring samples, variations in mud temperature, and ROP. The mud logging data are indicated on the master log but are not available in digital format. A temperature log was measured in the well but not under thermal equilibrium conditions, as was the case in GPK-2, GPK-3, and GPK-4. Because this thermal profile is plotted in its own depth reference framework, there is a depth matching shift of $+2 \mathrm{~m}$ between the thermal profile and the other well log curves (Figure 8). The wireline logging data collected in the sedimentary part of GPK-1 are GR, bulk density, neutron porosity. The caliper was a two-orthogonal-arm tools with two measurements, CAL1 and CAL2. The nominal diameter for this depth section was 12.25 inches.

Six fracture zones were observed in the sedimentary part of GPK-1 between 740- and 1,300-m depth (Figure 8).

Only zone F7 featured mud losses. The existence and locations of zones F1 to F6 were deduced from the presence of variations in at least two well log parameters.

Zone $\mathrm{F} 1$ presents a clear negative thermal anomaly of $-3^{\circ} \mathrm{C}$ at $750 \mathrm{~m}$, which correlates with a cave only visible on CAL1 between 747- and 754-m depth and with an increase in the ROP. This zone is the only fracture zone with a sharp caliper variation. Deeper in the sedimentary cover, the caliper curves are smooth, and it is rather difficult to observe peaks associated with fracture zones. Zone F1 is a partly sealed fracture zone located in the Upper Keuper formation, which is composed of fine, colored clays in the uppermost part and fine-grained sandstones at the base. 


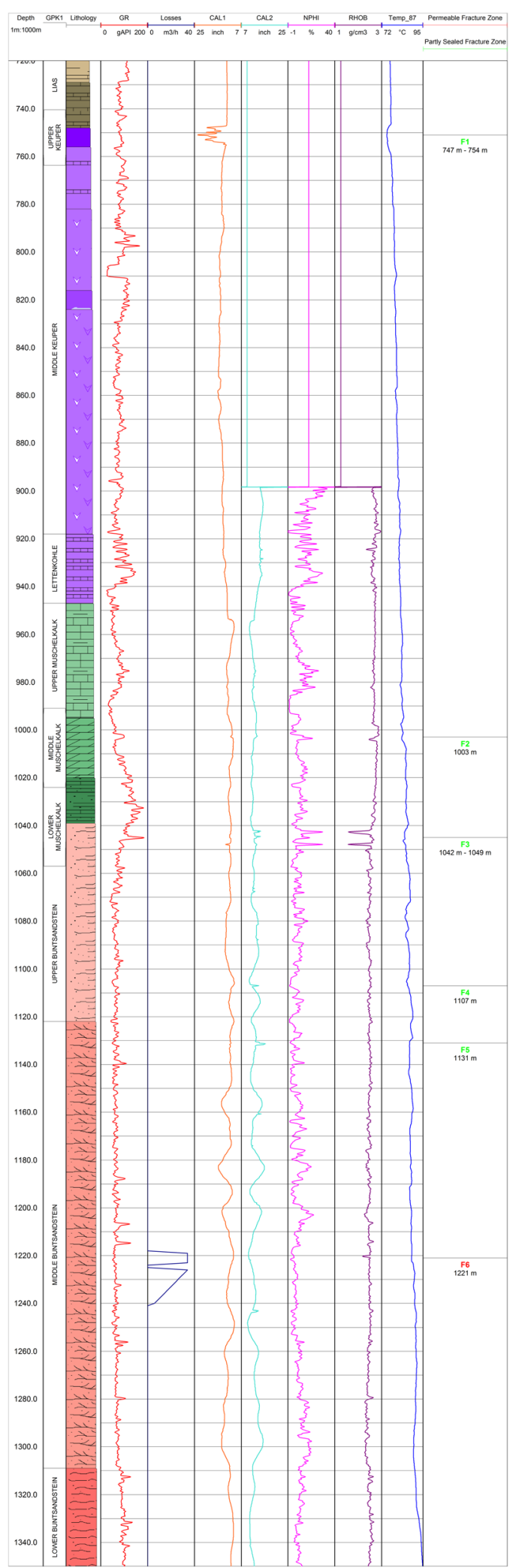

Figure 8 (See legend on next page.) 
(See figure on previous page.)

Figure 8 Synthetic log of GPK-1. The synthetic log shows lithology, mud losses, GR, neutron porosity (NPHI), bulk density (RHOB), calipers (CAL1 and CAL2), and temperature data (Temp87). Fracture zones are indicated: F1 to F6. Permeable zones are in red and partly sealed zones are in green. Depths are expressed in measured depth.

A small temperature anomaly is visible at $981-\mathrm{m}$ depth, which correlates with a small anomaly in the density log. The size of this anomaly is too small to assume that a fracture zone is present.

Zone F2 is characterized by a small negative temperature variation $\left(-1^{\circ} \mathrm{C}\right)$ at a depth of 1,003 m, which matches the depth of a weak caliper variation for both CAL1 (11.12 inches) and CAL2 (12.84 inches). The GR data include a peak of 99.37 gAPI over a 2-m-thick zone at 1,003-m depth. At the same depth, the neutron porosity reaches $20.50 \%$, and bulk density decreases to $2.53 \mathrm{~g} / \mathrm{cm}^{3}$. F2 is a single, partly sealed fracture.

Between 1,042- and 1,049-m depth, several caliper peaks are visible for CAL1 (12.97 inches at 1,048 m) and CAL2 (12.82 inches, also at 1,048 m). These peaks match the depths of variations in the neutron porosity $(28.67 \%$ at $1,048 \mathrm{~m})$ and bulk density variation $\left(1.65 \mathrm{~g} / \mathrm{cm}^{3}\right.$ also at $\left.1,048 \mathrm{~m}\right)$. At 1,046-m depth, the thermal profile obtained after drilling features a cooled zone $\left(-1.00^{\circ} \mathrm{C}\right)$ due to mud invasion. F3 is a complex, partly sealed fracture zone.

In zone F4, a cave occurrence is clearly visible in the CAL2 data, 13.93 inches at $1,107-\mathrm{m}$ depth, which is associated with a temperature variation of $-2^{\circ} \mathrm{C}$ at $1,105 \mathrm{~m}$. There is no indication of permeability; thus, F4 is a single, partly sealed fracture.

Zone F5 is visible on both calipers at 1,131-m depth, where a small variation in CAL1 (11.49 inches) and a strong variation in CAL2 (16.34 inches) are associated with a positive anomaly of $+1^{\circ} \mathrm{C}$ on the thermal profile at 1,129-m depth. Similar to F4, there is no mud logging variation, and F5 is a single, partly sealed fracture.

Mud loss was total at 1,221-m depth and decreased slowly with increasing depth. The ROP shows several positive peaks, but caliper variations are not clearly visible. After drilling operations, the thermal profile reveals small variations. Zone F6 is a single permeable fracture.

\section{Well EPS-1}

For older oil wells, the interpretation of mud logging and geophysical logs is much more challenging because the drilling data are not always available. However, the continuous coring of EPS-1, in particular for the interval from 930- to 1,417-m depth, provides a direct view of the natural fractures in the sedimentary part. Based on the continuous core survey in the Buntsandstein formations, a structural analysis of the fracture network has been performed. Fracture location, typology, nature of hydrothermal filling, and the fracture thickness data sets were collected (Vernoux et al. 1995; Genter et al. 1997). The longest naturally fractured zone is located between 1,170- and 1,215-m depth and is characterized by euhedral barite, galena, pyrite, and geodic quartz. The location of this zone matches perfectly with mud losses observed from the drilling survey (Degouy et al. 1992). Partial mud losses were observed at approximately 1,204-m depth in EPS-1 in the Intermediate Buntsandstein formations. At the same depth, borehole image logs indicate that the orientation of this main permeable fracture 
strikes N-S and dips westward (Figure 9). The core sample indicates that barite and galena have filled the fracture zone (Genter et al. 1997) (Figure 4).

The thermal profile available in the sedimentary part of EPS-1 has been obtained from within the casing. The thermal gradient presents the same trend as in the other Soultz wells. In the uppermost part, it is on the order of $100^{\circ} \mathrm{C} / \mathrm{km}$, revealing a conduction regime. Below $1 \mathrm{~km}$, it decreases to $5^{\circ} \mathrm{C} / \mathrm{km}$. However, in this convectiondominated part, there is no impact of the fracture zone at 1,204-m depth behind the casing or any other perturbations related to the geological formations.

\section{Well 4550}

For the seismic well 4550, a BHTV log was the only geophysical well log available to correlate with mud losses recorded by the driller. A total loss was recorded at 1,280-m depth in the Intermediate Buntsandstein. A fracture zone, dipping westward and composed of a conjugate fracture system, is clearly visible on the BHTV log, as well as on a caliper log with the occurrences of well enlargement (caving) (Dezayes et al. 2010) (Figure 10). This fracture zone could have been produced by artesian flow of approximately $30 \mathrm{~m}^{3} / \mathrm{h}$ at $125^{\circ} \mathrm{C}$ with a natural productivity approximately $30 \mathrm{l} / \mathrm{s} /$ bar (Degouy

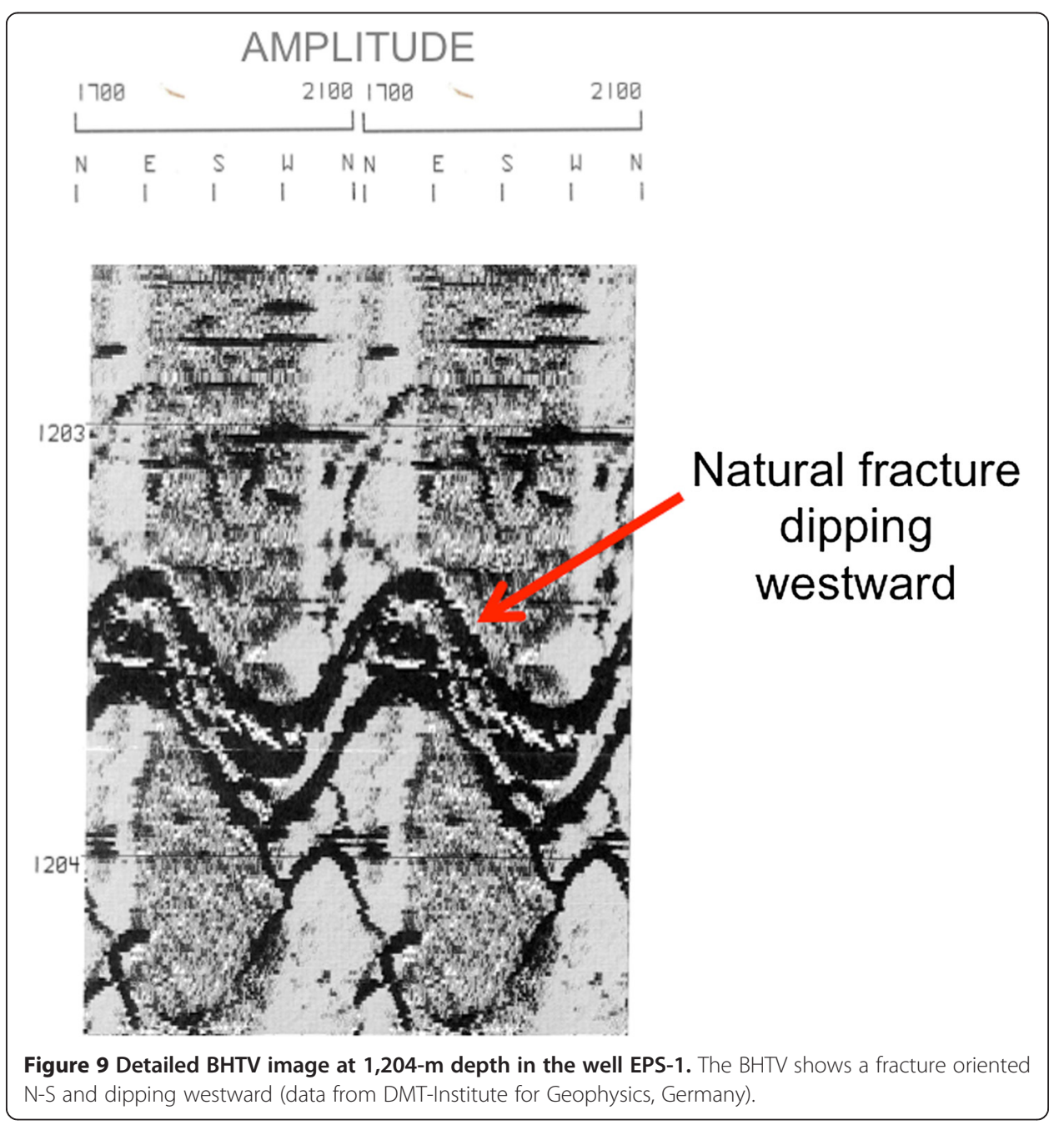




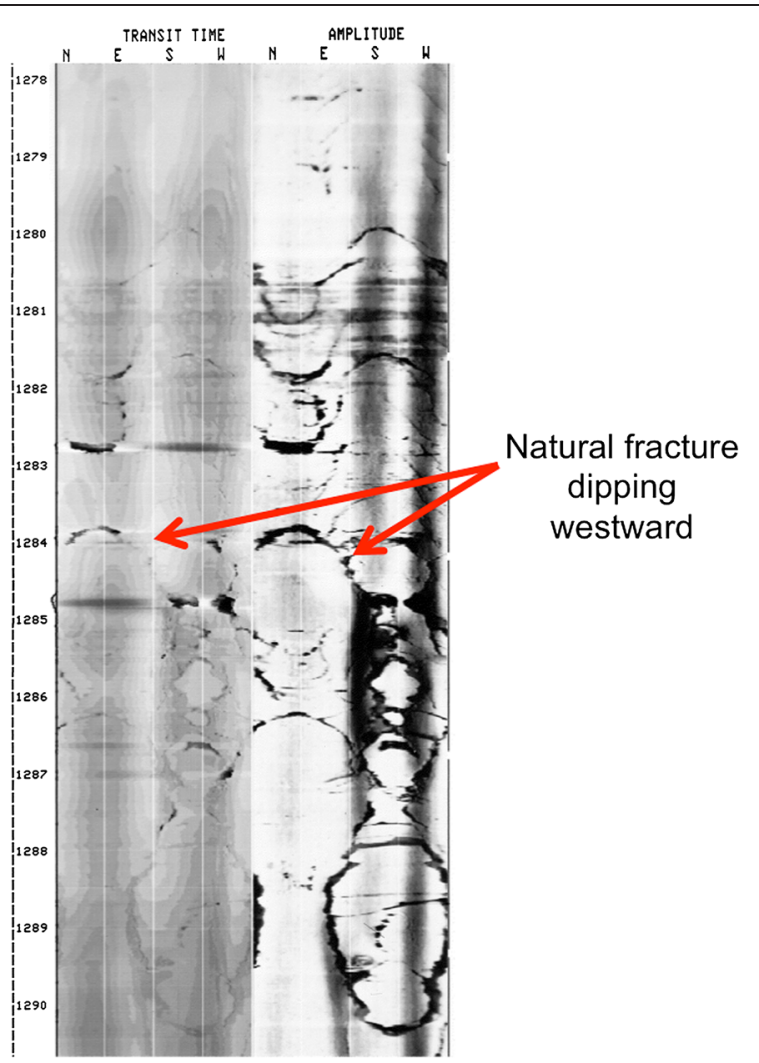

Figure 10 Detailed BHTV image at 1,280-m depth in the well 4550. The BHTV shows a conjugate fracture system with a major structure dipping westward (data from GEIE EMC, France).

et al. 1992). The thermal profile in the 4550 well shows an upper part dominated by conduction with a thermal gradient of $105^{\circ} \mathrm{C} / \mathrm{km}$. Below the depth of $800 \mathrm{~m}$, the thermal gradient decreases to $30^{\circ} \mathrm{C} / \mathrm{km}$, corresponding to a convective regime. At 1,280$\mathrm{m}$ depth, the occurrence of a sharp negative thermal anomaly is clearly visible and fits with the permeable fracture zone location (Figure 11).

Sausse et al. (2010) analyzed the same fracture zones in the sedimentary cover for the wells GPK-1, EPS-1, and 4550 but only from a geometrical point of view. Their locations in the different wells are roughly located at the same depth.

\section{Correlation of permeability between the wells}

Fracture zone correlation between the Soultz wells has already been investigated but only in the granitic basement (Valley 2007; Sausse et al. 2010). By using various geometric correlation methods, Valley (2007) demonstrated that the extrapolation of a given fracture zone visible in one well is rather difficult to identify in a second spatially close well. In this study, the authors made spatial correlations of fracture zone permeability in the sedimentary part of the geothermal boreholes GPK-2, GPK-3, and GPK-4. In total, nine fracture zones have been identified with and without permeability indications (Table 1). Two zones have been located in the Muschelkalk formations with indications of permeability (Figure 12). These two zones represent a complex structure with an apparent thickness between 5 and $20 \mathrm{~m}$ (Figures 5, 6, and 7). They are composed of many individual fractures that are partly filled with hydrothermal deposits. 


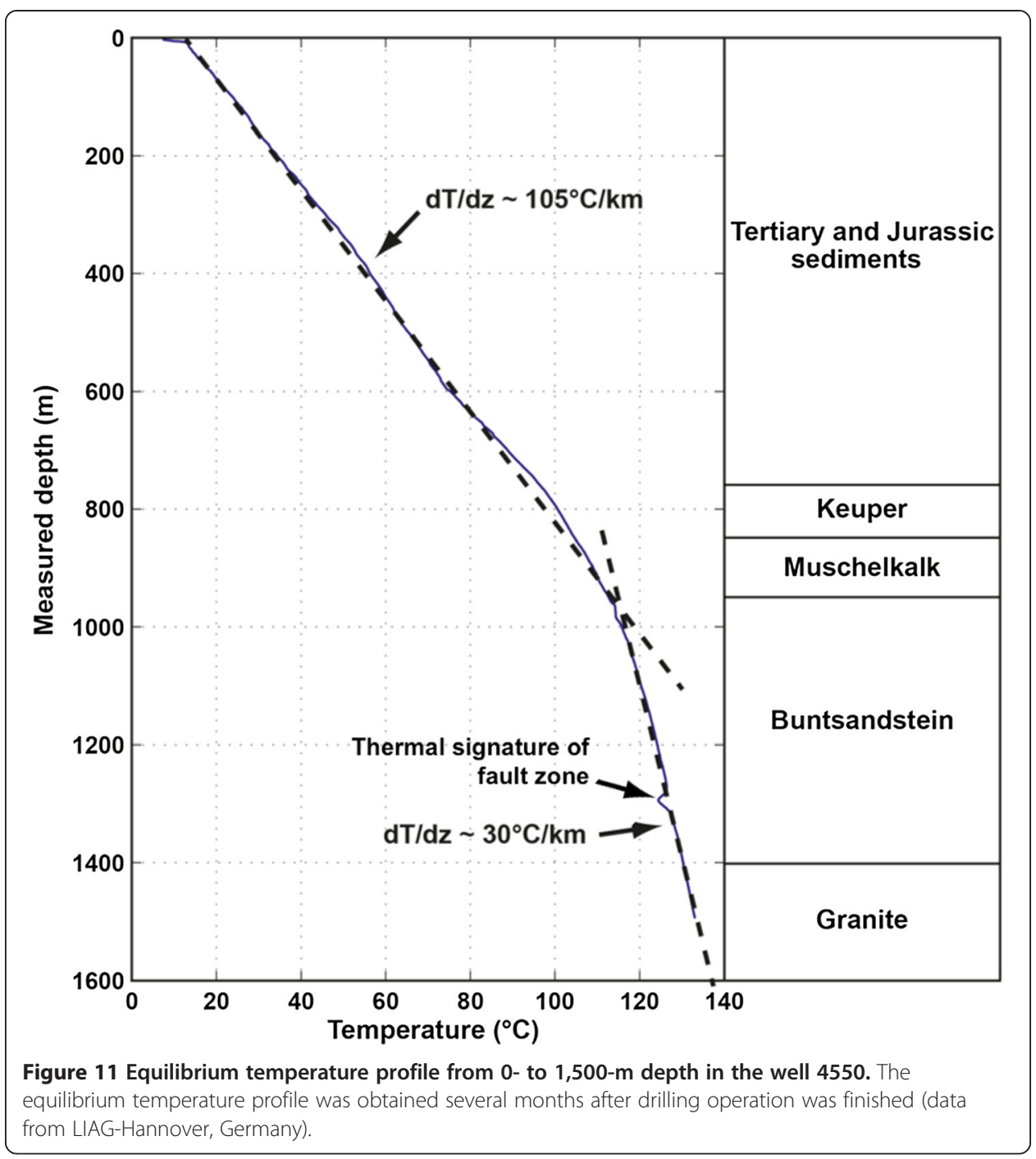

Table 1 Permeability properties of fracture zones detected in the Muschelkalk and Buntsandstein formations

\begin{tabular}{clll}
\hline & GPK-2 & GPK-3 & GPK-4 \\
\hline Muschelkalk & Permeable & Permeable & \\
Z1 & Permeable & Permeable & Permeable \\
Z2 & Sealed & Sealed & \\
Z3 & & & \\
Buntsandstein & & Sealed & Partly sealed \\
Z4 & Sealed & & \\
Z5 & Sealed & Sealed & Sealed \\
Z6 & Sealed & & Permeable \\
Z7 & Sealed & Sealed & Sealed \\
Z8 & Permeable & Permeable & Partly sealed \\
\hline
\end{tabular}

In the geothermal boreholes GPK-2, GPK-3, and GPK-4 


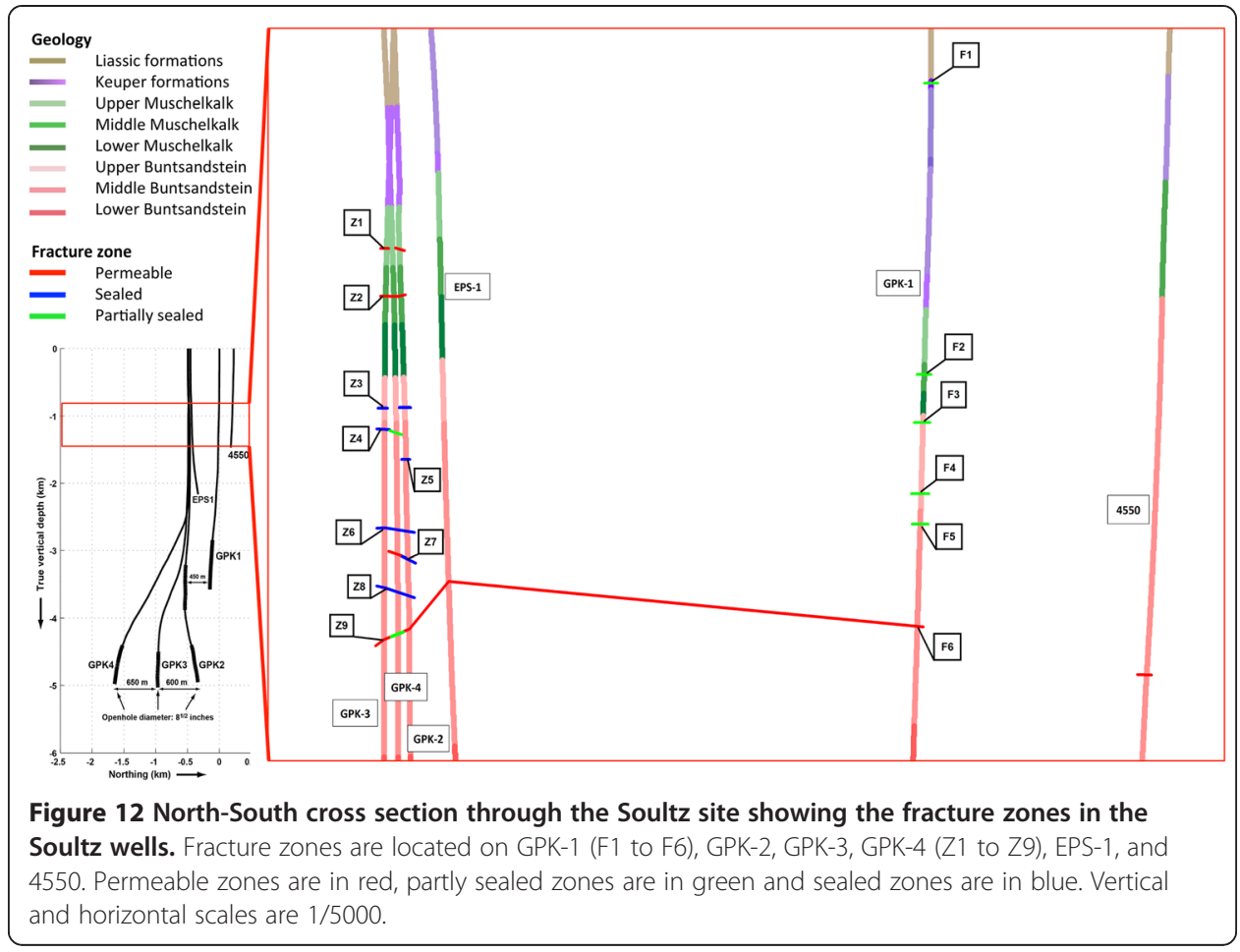

Zone Z1 intercepts GPK-2 and GPK-3, whereas zone Z2 crosses all three wells. As image logs have not been acquired in the Muschelkalk, it is rather difficult to derive a $3 \mathrm{D}$ organization of those thick structures visible at the same depth in closely spaced vertical boreholes.

Seven fracture zones have been interpreted in the Buntsandstein formations. Four zones do not show clear permeability indications (Z3, Z5, Z6, and Z8), whereas Z9 is a complex permeable fracture zone observed in three wells with evidence of natural outflow in GPK-2 and GPK-3. Zone Z4 is permeable only in GPK-3 and zone Z7 is permeable in GPK-3 and GPK-4. Sealed fracture zones correspond to both single fractures (Z3, Z4, and Z7) and complex structures (Z5, Z6, and Z8). Zone Z6 is the only sealed fracture zone that intercepts all three wells (Figure 12). All other sealed fracture zones in the Buntsandstein are visible in two wells, with the exception of Z5, which is only visible in GPK-2.

Fracture zones derived from mud logging and geophysical data in the Muschelkalk and Buntsandstein are not observed in the thermal profile obtained under thermal equilibrium conditions (Figure 2).

Six fracture zones have been outlined in GPK-1: in the Upper Keuper (F1), in the Muschelkalk (F2) and in the Buntsandstein (F3 to F6). All of them are associated with thermal variations, but only F6 correlates with mud losses (Figure 8).

In EPS-1, only one complex fracture zone (at a depth of 1,204 m) correlates with mud losses.

In Buntsandstein formations, the complex permeable fracture zone Z9, visible in GPK-2, GPK-3, and GPK-4, could be correlated with zone F6 in GPK-1 and the permeable zone in EPS-1 (Figure 12). This fracture zone could fit with a branch of the Soultz fault visible at the local scale (Figure 1). 


\section{Interpretation of thermal profile and convective cells}

Under thermal equilibrium conditions, a conduction regime is dominant in the Tertiary, Jurassic, and the top of the Triassic sedimentary formations (0- to 800-m depth). Within the deepest Mesozoic sedimentary formations (Muschelkalk and Buntsandstein) and in the top of the granitic basement, the heat transport process is dominated by convection. The depth section 880 to 1,000 m, i.e., the base of the Muschelkalk and the top of Buntsandstein, contains permeable fracture zones and corresponds to a transition from a conduction to a convective thermal regime. This indication suggests that this zone is the top of the convective cells and that fluids cannot move upward within the fractures located above the Muschelkalk formations. The horizontal bounding layer at the top of the convective cells could correlate with the Keuper formation (Upper Triassic). Convection arises in the granitic section.

Based on various borehole data sets, we propose a conceptual model of the convective cell structure at the sediment-basement interface (Figure 13). Fracture zones in the Muschelkalk and in the Buntsandstein have been highlighted in GPK-2, GPK-3, and GPK-4 at Soultz. Above these formations, i.e., between the Tertiary formations and the lower part of the Upper Triassic (Keuper), there is no obvious evidence of permeable or sealed fractures from the mud logging and well logging data except in GPK-1, where two permeable fracture zones were found in the Keuper formation. Below the Triassic formations, in the granitic basement, the permeable or sealed fracture zones are widely documented. Natural permeability in the granite is related to hydrothermally altered fracture zones. This permeability is evidenced by brine occurrences (the formation fluid has $100 \mathrm{~g} / \mathrm{L}$ of dissolved solids) (Vuataz et al. 1990). The highest drilling mud losses

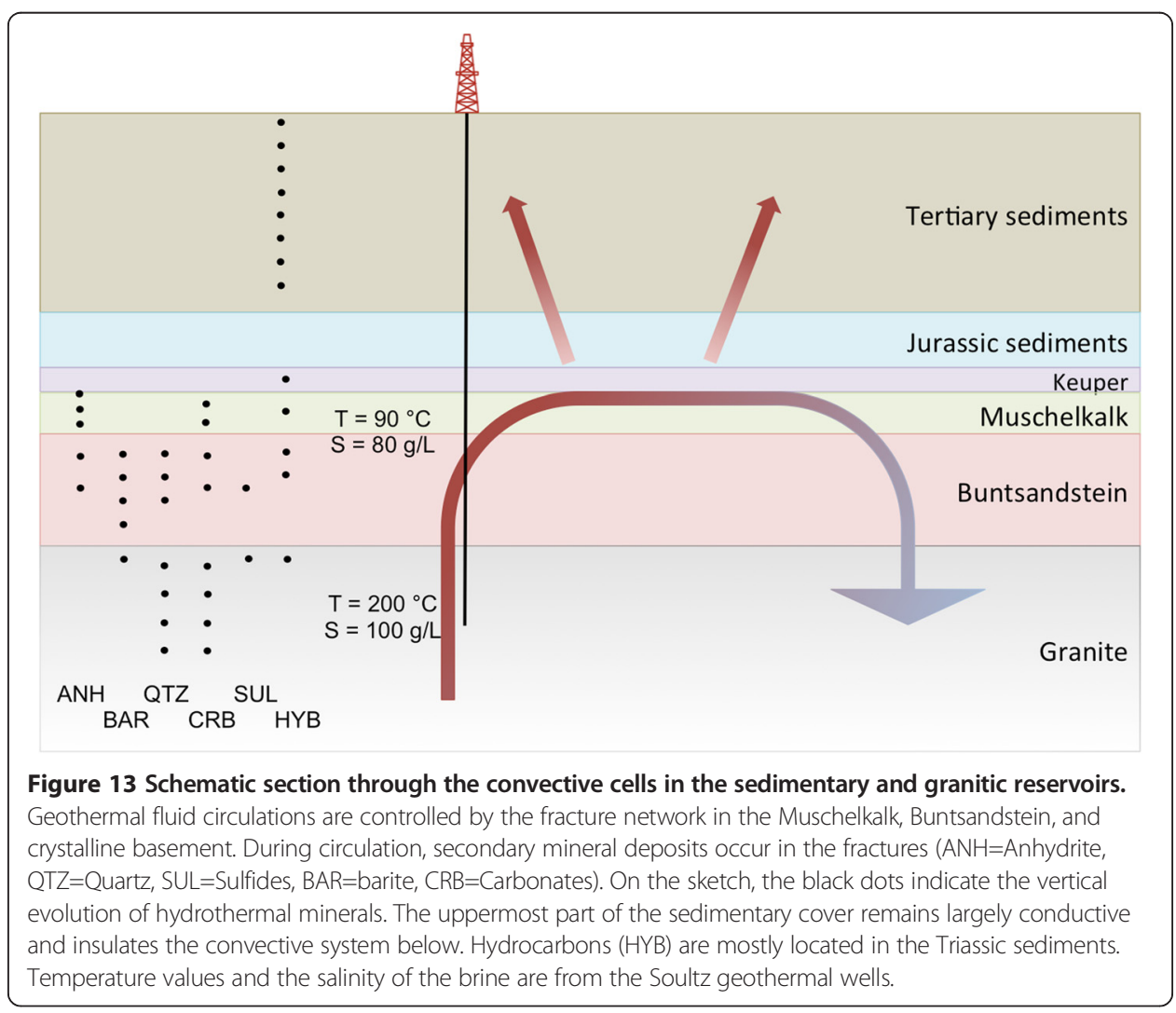


have been observed in the granitic basement and are clearly related to fracture zones (Evans et al. 2005; Dezayes et al. 2010). This fracture network controls the convection, especially between 1,400- and 3,500-m depth in the granite (Figure 2). At the scale of the Soultz site, the lower part of the convective cells initiates at approximately $3.5-\mathrm{km}$ depth in the fractured and altered granite at $160^{\circ} \mathrm{C}$. Hydrothermal fluids percolate through the sub-vertical fault system. During its ascent, the formation fluids precipitate minerals, primarily quartz and carbonates and more locally sulfates and sulfides (Figure 13). Based on a fluid inclusion study of quartz and carbonate veins, Dubois et al. (2000) demonstrated that the minerals precipitated in the same temperature-pressure range and under conditions similar to the present day conditions. This study shows that the ascending fluids are recent and sealed the fracture system. Due to the structural history of this area, the fracture system is also well developed in the sedimentary pile overlying the granite, including small-scale fractures and large-scale faults. For example, at the seismic scale, steeply dipping normal faults intersect both the granitic basement and its sedimentary cover (Figure 1). During its ascent and after passing out of the crystalline basement, hydrothermal fluids could circulate in fractures in the Lower Triassic sandstones (Buntsandstein) and then in the Middle Triassic limestones (Muschelkalk). In the sandstones, similar hydrothermal mineral assemblages precipitated and partly plugged the vertical fracture system (Vernoux et al. 1995). In those layers, the temperature is lower, decreasing from $140^{\circ} \mathrm{C}$ to $90^{\circ} \mathrm{C}$ in the section ranging from 1,400 - to 1,000-m depth. In the limestones, the main hydrothermal deposits are anhydrite and carbonates (Figure 13). The Upper Triassic formation (Keuper) is the shallowest sedimentary fractured layer with permeability indicators. The vertical fluid circulation could transition towards a horizontal circulation under the Tertiary and the Jurassic sediments. This interface could govern the top of the convection cells, and it is characterized by lateral flow and most likely temperature decreases. The heat carried by the hydrothermal fluid is most likely dissipated vertically to the overlying sediments. It generates the conductive section with the high geothermal gradient of $110^{\circ} \mathrm{C} / \mathrm{km}$. At the top of the permeable reservoir, fluids must flow out laterally and may descend again in the natural fracture system from the Triassic sediments to the granitic basement, due to their increasing density upon cooling. Occurrences of organic matter inside the deep fractured and altered granitic zone demonstrate communication with the sediments (Ledésert et al. 1996). This convective cell structure indicates ancient and recent fluid circulation across the sediment-basement interface. This conceptual model does not take into account time and size constraints, but hydrothermal circulation is clearly at the root of the geothermal anomaly.

Various borehole data collected in the Soultz wells outline permeable fractures in both the sediments and the basement. During the fluid's ascent, the temperature decreases; consequently, the high salinity fluid precipitates minerals. Therefore, permeability decreases vertically, whereas the fracture sealing increases. Thus, the top of the convective cells could fit with reduced permeability in the brittle sedimentary layers. The top boundary layers made of late Jurassic and Tertiary sedimentary deposits have a low permeability and a low thermal conductivity due to occurrences of clay-rich formations.

This cap rock, which consists of the uppermost sedimentary section down to the depth of $800 \mathrm{~m}$ insulates the more brittle underlying formations and underlines the 
contrast of the mechanical properties of the two units. In the soft sediments of the cap rock, brittle deformation is rather limited and faults do not exhibit permeability. In the brittle formations below a depth of approximately $1 \mathrm{~km}$, natural fractures are developed over geological time, allowing circulation of hydrothermal fluids (permeability) and deposition of secondary minerals (sealing). The competition between the natural permeability and the mineral deposition characterizes the fractures located at the top of the convective cells.

\section{Conclusions}

The combined analysis of mud logging and well logging data from the sedimentary cover of several geothermal wells at the Soultz site in the URG reveals the presence of fracture zones in the Triassic sedimentary formations. These fracture zones are made of individual or complex structures. The complex structures most likely represent faulted zones crosscutting the deepest sediments of the Tertiary basin. Based on mud loss occurrences, it has been shown that fracture permeability is associated mainly with complex fracture zones located in the Middle Muschelkalk limestones and Middle Buntsandstein sandstones. At the borehole scale, many fracture zones are sealed due to the occurrence of secondary precipitated mineral, which most likely reduce the permeability.

The natural permeability in the sub-vertical fracture zone reveals the geothermal fluid pathways. A schematic conceptual model of the top of a convective cell has been proposed : hot natural fluids move upward under buoyancy from the top of the crystalline basement into the Triassic sediments and then migrate laterally before circulating downward. The top of the convection is characterized by reduced permeability due to partial hydrothermal seals. There, complex permeable fracture zones are most likely connected to large-scale faults and small-scale fracture networks at the sedimentbasement interface and control the top of the thermal convection loop.

Competing interests

The authors declare that they have no competing interests.

\section{Authors' contributions}

JV and AG did the data analysis, comparison, and interpretation. JV, AG, and JS contributed to the conceptual model. All the authors read and approved the final manuscript.

\section{Acknowledgements}

A part of this work was conducted in the framework of the Labex G-Eau-Thermie Profonde, which is co-funded by the French government under the program 'Investissements d'Avenir'. The manuscript was performed as a contribution to the PhD thesis of Jeanne Vidal co-founded by ADEME (French Agency for Environment and Energy). The authors acknowledge the GEIE EMC and the LIAG for providing Soultz boreholes data and Dr. Nicolas Cuenot and Dr. Thomas Koelbel for support. Finally, the authors would like to kindly thank Robert Hopkirk for his full check of the English language and the anonymous reviewers for their contributions and manuscript improvement.

\section{Author details}

${ }^{1}$ EOST, University of Strasbourg, 1 rue Blessig, 67084 Strasbourg Cedex, France. ${ }^{2}$ GEIE, Exploitation Minière de la Chaleur, Route de Soultz BP 40038c, 67250 Kutzenhausen, France. ${ }^{3}$ Now at: Es-Géothermie, 3A chemin du Gaz, 67500 Haguenau, France. ${ }^{4}$ EOST, University of Strasbourg, 5 rue René Descartes, 67084 Strasbourg Cedex, France.

Received: 12 June 2014 Accepted: 7 January 2015

Published online: 18 April 2015

References

Baechler D, Kohl T, Rybach L (2003) Impact of graben-parallel faults on hydrothermal convection-Rhine Graben case study. Phys Chem Earth 28:341-441

Baillieux P, Schill E, Edel J-B, Mauri G (2013) Localization of temperature anomalies in the Upper Rhine Graben: insights from geophysics and neotectonic activity. International Geology Review. doi: 10.1080/00206814.2013.794914

Baumgärtner J, Lerch C (2013) Geothermal 2.0: The Insheim Geothermal Power Plant. the second generation of geothermal power plants in the Upper Rhine Graben. Proceedings of Third European Geothermal Review, June 2013 
Baumgärtner J, Moore PL, and Gérard A (1995) Drilling of hot and fractured granite at Soultz-sous-Forêts. Proceedings of World Geothermal Congress 1995, Florence, Italy, 1995

Baumgärtner J, Gérard A, Baria R (2000) Soultz-sous-Forêts: main technical aspects of deepening the well GPK-2, Proceedings of World Geothermal Congress. Kyushu Tohoku, Japan

Baumgärtner J, Teza D, Hettkamp T, Homeier G, Baria R, Michelet S (2005) Electricity production from hot rocks. Proceedings of World Geothermal Congress. Antalya, Turkey

Benderitter Y, Elsass Ph (1995) Structural control of deep fluid circulation at the Soultz HDR Site, France. Geothermal Science and Technology 227-237

Cautru JP (1988) Coupe géologique passant par le forage GPK-1 calée sur la sismique réflexion. Institut Mixte de Recherches Géothermiques, BRGM

Degouy M, Villeneuve B, Weber R (1992) Logistical support and development of the Soultz Hot Dry Rock site: seismic observation wells and well EPS-1, final drilling report. Technical Report RR-41179-FR, BRGM, CFG 009, Comission of European Communitie

Dezayes C, Genter A, Valley B (2010) Structure of the low permeable naturally fractured geothermal reservoir at Soultz. Compt Rendus Geosci 342:517-530

Dubois M, Ledésert B, Potdevin JL, Vançon S (2000) Détermination des conditions de précipitation des carbonates dans une zone d'altération du granite de Soultz (soubassement du fossé Rhénan, France): I'enregistrement des inclusions fluides. C R Acad Sci Paris, Ser 331:303-309

Evans K, Genter A, Sausse J (2005) Permeability creation and damage due to massive fluid injections into granite at 3.5km at Soultz. Journal of Geophysical Research, 110. doi: 10.1029/2004JB003168

Genter A (1989) Géothermie roches chaudes sèches: le granite de Soultz-sous-Forêts (Bas-Rhin, France). Fracturation naturelle, altérations hydrothermales et interaction eau-roche. PhD thesis, University of Orléans, France

Genter A, Traineau H (1992) Borehole EPS-1, Alsace, France: preliminary geological results from granite core analyses for Hot Dry Rock research. Scientific Drill 3:205-214

Genter A, Traineau H (1996) Analysis of macroscopic fractures in granite in the HDR geothermal well EPS-1, Soultz-sousForêts, France. J Volcanol Geotherm Res 72:121-141

Genter A, Castaing C, Dezayes C, Tenzer H, Traineau H, Villemin T (1997) Comparative analysis of direct (core) and indirect (borehole imaging tools) collection of fracture data in the Hot Dry Rock Soultz reservoir (France). J Geophys Res 102(B7):15,419-15,431

Genter A, Traineau H, Ledésert B, Bourgine B, Gentier S (2000) Over 10 years of geological investigations within the HDR Soultz project, France. Proceedings of World Geothermal Congress 2000, Kyushu Tohoku, Japan, May-June 2000

Genter A, Evans K, Cuenot N, Fritsch D, Sanjuan B (2010) Contribution of the exploration of deep crystalline fractured reservoir of Soultz to the knowledge of enhanced geothermal system (EGS). Compt Rendus Geosci 342:502-516

Genter A, Cuenot N, Melchert B, Moeckes W, Ravier G, Sanjuan B, Sanjuan R, Scheiber J, Schill E, Schmittbuhl J (2013) Main achievements from the multi-well EGS Soultz project during geothermal exploitation from 2010 and 2012. Proceedings of European Geothermal Congress 2013, Pisa, Italy, June 2013

Gérard A, Genter A, Kohl T, Lutz P, Rose P, Fritz R (2006) The deep EGS (Enhanced Geothermal System) project at Soultz-sous-Forêts (Alsace, France). Geothermics 35:473-483

Guillou-Frottier L, Carré C, Bourgine B, Bouchot V, Genter A (2013) Structure of hydrothermal convection in the Upper Rhine Graben as infered from corrected temperature data and basin-scale numerical models. J Volcanol Geotherm Res 256:29-49

Haffen S, Géraud Y, Diraison M, Dezayes C (2013) Determining fluid-flow zones in a geothermal sandstone reservoir from thermal conductivity and temperature logs. Geothermics 48:32-41

Herbrich B (1988) Le forage géothermique de Soultz-sous-Forêts (GPK-1), rapport de fin de sondage. Technical Report 29421, CFG 003

Hettkamp T, Baumgärtner J, Baria R, Gérard A, Gandy T, Michelet S, Teza D (2004) Electricity production from hot rocks. Proceedings of Twenty-Ninth Workshop on Geothermal Reservoir Engineering, number SGP-TR-175, Stanford University, California, January 2004

Hettkamp T, Baumgärtner J, Teza D, Lerch C (2013) Experiences from 5 years operation in Landau. Proceedings of Third European Geothermal Review, June 2013

Hooijkaas GR, Genter A, Dezayes C (2006) Deep-seated geology of the granite intrusions at the Soultz EGS site based on data from $5 \mathrm{~km}$-deep boreholes. Geothermics 35:484-506

Housse BA (1984) Reconnaissance du potentiel géothermique du Buntsandstein à Strasbourg-Cronenbourg. Géothermie Actualités 1

Kohl T, Baechler D, Rybach L (2000) Steps towards a comprehensive thermo-hydraulic analysis of the HDR test site Soultz-sous-Forêts. Proceedings of World Geothermal Congress 2000, Kyushu Tohoku, Japan, May-June 2000

Koelbel T, Genter A, Cuenot N, Baumgärtner J, Perret E, Schlagermann P (2011) Soultz-sous-Forêts: Von der Reservoirentwicklung zur Stromerzeugung. GeoTherm Congress, Offenburg, Germany, 24-25 February 2011

Kreuter H, Harthill N, Judt M, Lehmann B (2003) Geothermal power generation in the Upper Rhine Valley, the project Offenbach/Pfalz. Proceedings of International Geothermal Conference 2003, Reykjavik, Island, September 2003

Le Carlier C, Royer JJ, Flores LE (1994) Convective heat transfer at the Soultz-sous-Forêts geothermal site: implications for oil potential. First Break 12(11):553-559

Ledésert B, Joffre J, Amblès A, Sardini P, Genter A (1996) Organic matter in the Soultz HDR granitic thermal exchanger (France): natural tracer of fluid circulations between the basement and its sedimentary cover. J Volcanol Geotherm Res 70:235-253

Meixner J, Schill E, Gaucher E, Kohl T (2014) Inferring the in situ stress regime in deep sediments: an example from the Bruchsal geothermal site. Geothermal Energy 2(1):7, Doi: 10.1186/s40517-014-0007-z

Ménillet F (1976) Notice de la carte géologique 1/50000 de Haguenau. Carte géologique de la France, Service géologique national, BRGM

Person M, Garven G (1992) Hydrologic constraints on petroleum generation within continental rift basins: theory and application to the Rhine Graben. AAPG Bull 76(4):468-488

Pribnow D, Clauser C (2000) Heat and fluid flow at the Soultz Hot Dry Rock system in the Rhine Graben. Proceedings of World Geothermal Congress 2000, Kyushu Tohoku, Japan, May-June 2000 
Pribnow D, Schellschmidt R (2000) Thermal tracking of upper crustal fluid flow in the Rhine Graben. Geophysical Research Letters 27

Rummel F, Haack U, Gohn E (1988) Uranium, thorium and potassium content and derived heat production rate for the granite cores in GPK-1. Ruhr Universität Bochum Yellow Reports 6:9

Sausse J, Dezayes C, Dorbath L, Genter A, Place J (2010) 3D model of fracture zones at Soultz-sous-Forêts based on geological data, image logs, induced microseismicity and vertical seismic profiles. Compt Rendus Geosci 342:531-545

Schellschmidt R, Clauser C (1996) The thermal regime of the Upper Rhine Graben and the anomaly at Soultz. Z Angew Geol 12:40-44

Stober I, Jodocy M (2009) Eigenschaften geothermischer Nutzhorizonte im baden-württembergischen und französischen Teil des Obberrheingrabens. Grundwasser - Zeitschrift der Fachsektion Hydrogeologie 14:127-137

Stober I, Jodocy M (2011) Hydrochemical characteristic of deep seated waters in the Upper Rhine Graben. Basic information for geothermal energy Zeitschrift für Geologische Wissenschaften 39:39-57

Stussi JM, Cheilletz A, Royer JJ, Chèvremont P, Gilbert F (2002) The hidden monzogranite of Soultz-sous-Forêts (Rhine Graben, France), mineralogy, petrology and genesis. Géol Fr 1:45-64

Valley BC (2007) The relation between natural fracturing and stress heterogeneities in deep-seated crystalline rocks at Soultz-sous-Forêts (France). PhD thesis, Swiss Federal Institute of Technology Zurich, Switzerland

Vernoux JF, Genter A, Razin Ph, Vinchon C (1995) Geological and petrophysical parameters of a deep fractured sandstone formation as applied to geothermal exploitation: EPS-1 borehole, Soultz-sous-Forêts, France. Technical Report R 38622, BRGM

Villadangos G (2013) ECOGl, EGS Upper Rhine Geothermal project for the industry, first well and result. Proceedings of Third European Geothermal Review, June 2013

Vuataz FD, Brach M, Criaud A, Fouillac Ch (1990) Geochemical monitoring of drilling fluids: a powerful tool to forecast and detect formation waters. SPE Formation Evaluation: 177-184

\section{Submit your manuscript to a SpringerOpen ${ }^{\circ}$} journal and benefit from:

- Convenient online submission

- Rigorous peer review

- Immediate publication on acceptance

- Open access: articles freely available online

- High visibility within the field

Retaining the copyright to your article 